\title{
Dokumen Analisis Data Webinar Pra-Muktamar PCINU Sedunia
}

Kumpulan Analisis Data Webinar series Pra-Muktamar PCINU Sedunia

Disusun Oleh:

Ahmad Mustafid

Miftahussurur Hamidi Putra

Mochammad Miftah El Azmi Mauladi Tontowi

Muhammad Rodlin Billah 


\section{Kata Pengantar}

$$
\text { بِنْمِ اللَّهِ الرَّحْمَنِ الرَّحِيم }
$$

Assalamu'alaikum Wr. Wb.

Nahdlatul Ulama merupakan organisasi islam terbesar di dunia. Menyambut abad ke-2 Organisasi Nahdlatul Ulama merupakan momentum penting dalam perjalanan organisasi. Transformasi digital dalam tubuh Nahdlatul Ulama sangat perlu dilakukan untuk memutar roda organisasi kedepan. Langkah awal dalam transformasi digital adalah proses digitalisasi dan pemahaman yang baik atas data tersebut.

Pada momen menyambut Muktamar Nahdlatul Ulama yang ke-34, kami mencoba menyusun Dokumen Analisis Data Webinar Pra-Muktamar yang dilaksanakan oleh Pengurus Cabang Istimewa Nahdlatul Ulama (PCINU) Sedunia. Dokumen ini berisi seluruh data analisis yang bisa kami lakukan pada kegiatan tersebut. Semoga sumbangsih sedikit dari kami bisa bermanfaat untuk masa depan Organisasi Nahdlatul Ulama.

Wassalamu'alaikum Wr. Wb.

Ahmad Mustafid 


\section{Tim Penyusun}

Ahmad Mustafid (Data Analyst)

Miftahussurur Hamidi Putra (System Administrator)

Mochammad Miftah El Azmi Mauladi Tontowi (Designer)

Muhammad Rodlin Billah (Tanfidziyah PCINU Jerman) 


\section{Daftar Isi}

Dokumen Analisis Data Webinar Pra-Muktamar PCINU Sedunia 1

Kata Pengantar 2

Tim Penyusun 2

Daftar Isi $\quad 4$

$\begin{array}{ll}\text { Analisis Seri \#1 } & 7\end{array}$

$\begin{array}{ll}\text { Poster Acara } & 7\end{array}$

Seratus Tahun Nahdlatul Ulama,

Transformasi Digital di Lingkungan NU dan Pesantren, Perlukah? 8

$\begin{array}{ll}\text { Total Pengakses } & 8\end{array}$

Distribusi Pengakses Berdasarkan Waktu (CET/Central European Time Zone) 8

Jenis Perangkat Pengguna $\quad 8$

Distribusi Negara Pengakses $\quad 9$

Geografi Negara Pengakses $\quad 9$

Geografi Negara Pengakses (Eropa) 10

$\begin{array}{ll}\text { Distribusi Berdasarkan Kota } & 10\end{array}$

Analisis Seri \#2

Poster Acara $\quad 11$

Seratus Tahun Nahdlatul Ulama,

DIPLOMASI PERDAMAIAN \& DAKWAH INTERNASIONAL NU 12

$\begin{array}{ll}\text { Total Pengakses } & 12\end{array}$

Distribusi Pengakses Berdasarkan Waktu (CET/Central European Time Zone) 12

$\begin{array}{ll}\text { Jenis Perangkat Pengguna } & 12\end{array}$

Distribusi Negara Pengakses $\quad 13$

$\begin{array}{lr}\text { Geografi Negara Pengakses } & 13\end{array}$

Geografi Negara Pengakses (Eropa) 14

Distribusi Berdasarkan Kota 14

Analisis Seri \#3 $\quad 15$

$\begin{array}{lr}\text { Poster Acara } & 15\end{array}$

Seratus Tahun Nahdlatul Ulama,

Pendidikan, Manajemen Data, dan Transformasi SDM Nahdliyyin. 16

$\begin{array}{ll}\text { Total Pengakses } & 16\end{array}$

Distribusi Pengakses Berdasarkan Waktu (CET/Central European Time Zone) 16

$\begin{array}{lr}\text { Jenis Perangkat Pengguna } & 16\end{array}$

$\begin{array}{lr}\text { Distribusi Negara Pengakses } & 17\end{array}$

$\begin{array}{ll}\text { Geografi Negara Pengakses } & 17\end{array}$

$\begin{array}{ll}\text { Geografi Negara Pengakses (Eropa) } & 18\end{array}$ 
Analisis Seri \#4

Poster Acara

Menuju Abad Ke-2 Nahdlatul Ulama,

Digital Economy dan Halal Industri; Bagaimana Pesantren dan NU mempersiapkan? 20

$\begin{array}{ll}\text { Total Pengakses } & 20\end{array}$

Distribusi Pengakses Berdasarkan Waktu (CET/Central European Time Zone) 20

$\begin{array}{ll}\text { Jenis Perangkat Pengguna } & 20\end{array}$

Distribusi Negara Pengakses $\quad 21$

Geografi Negara Pengakses $\quad 21$

Geografi Negara Pengakses (Eropa) 22

Distribusi Berdasarkan Kota $\quad 22$

Analisis Seri \#5 23

Poster Acara $\quad 23$

Menuju Abad Ke-2 Nahdlatul Ulama,

Peran NU dalam Menjawab Tantangan Perubahan Iklim 24

$\begin{array}{ll}\text { Total Pengakses } & 24\end{array}$

Distribusi Pengakses Berdasarkan Waktu (CET/Central European Time Zone) 24

Jenis Perangkat Pengguna $\quad 24$

Distribusi Negara Pengakses $\quad 25$

Geografi Negara Pengakses $\quad 25$

Geografi Negara Pengakses (Eropa) 26

Distribusi Berdasarkan Kota 26

$\begin{array}{ll}\text { Analisis Seri \#6 } & 27\end{array}$

Poster Acara $\quad 27$

Aktualisasi peran NU dalam mewujudkan Kehidupan Sehat Sejahtera 2030

Menyongsong Indonesia Emas $2045 \quad 28$

$\begin{array}{ll}\text { Total Pengakses } & 28\end{array}$

Distribusi Pengakses Berdasarkan Waktu (CET/Central European Time Zone) 28

Jenis Perangkat Pengguna $\quad 28$

Distribusi Negara Pengakses $\quad 29$

Geografi Negara Pengakses $\quad 29$

Geografi Negara Pengakses (Eropa) $\quad 30$

Distribusi Berdasarkan Kota $\quad 30$ 
Poster Acara

Asa dekolonialisasi dan repatriasi pusaka dan manuskrip Nusantara yang berada di Europa

Total Pengakses

Distribusi Pengakses Berdasarkan Waktu (CET/Central European Time Zone) 32 Jenis Perangkat Pengguna $\quad 32$

Distribusi Negara Pengakses $\quad 32$

Geografi Negara Pengakses $\quad 33$

Geografi Negara Pengakses (Eropa) 34

Distribusi Berdasarkan Kota 34

$\begin{array}{ll}\text { Analisis Seri \#8 } & 34\end{array}$

Poster Acara $\quad 34$

Can We Expect Nahdlatul Ulama to Play A Role in Circular Economy in Indonesia 36

$\begin{array}{ll}\text { Total Pengakses } & 36\end{array}$

Distribusi Pengakses Berdasarkan Waktu (CET/Central European Time Zone) 36 Jenis Perangkat Pengguna 36

Distribusi Negara Pengakses $\quad 36$

Geografi Negara Pengakses $\quad 37$

Geografi Negara Pengakses (Eropa) 38

Distribusi Berdasarkan Kota 38 


\title{
Analisis Seri \#1
}

\author{
Poster Acara
}

\section{Webinar PCI NU se-Dunia menuju}
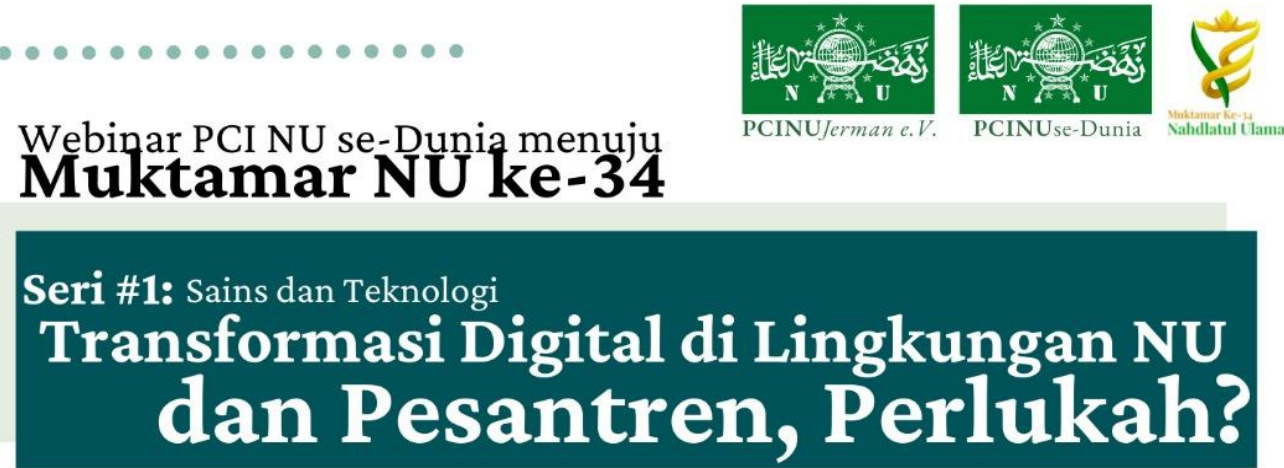

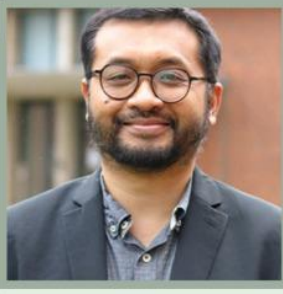

Narasumber 1

Prof. Hendro Wicaksono Professor Industrial Engineering Jacobs University Bremen

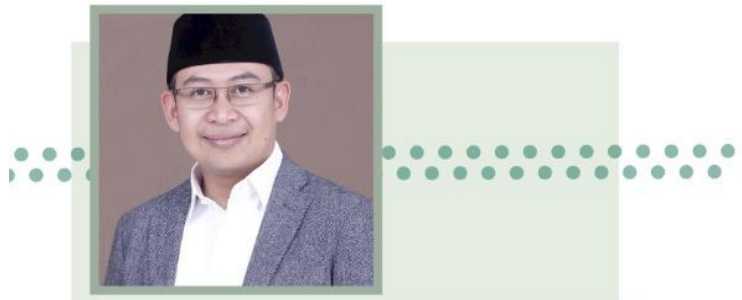

Narasumber 3

K.H. Abdul Ghaffar Rozin

Ketua Umum Pimpinan Pusat Rabithah Ma'ahid Islamiyah (RMI) PBNU

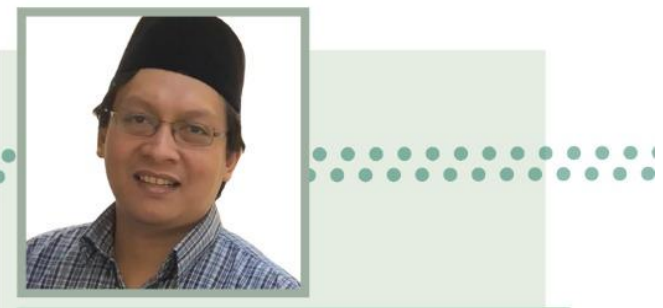

Narasumber 2

Wahyu Wijaya Hadiwikarta, PhD. IT Scientist \& Software Development, German Cancer Research Center

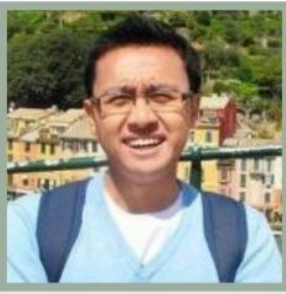

Moderator

Danu Pranantha, PhD.

A'wan PCINU Belanda, Expert Software Engineer di Bol.com

Hari/Tanggal: Sabtu, 11 Desember 2021

Pukul: 19:30 WIB / 13:30 CET

\section{Zoom Meeting}

Meeting ID: 89717467772

Password: 655710

Live!

Link: https://events.pcinu.de/webinar-muktamar-1

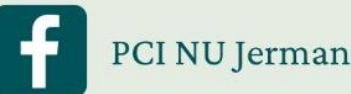

$\checkmark \quad$ NU Jerman 
Seratus Tahun Nahdlatul Ulama,

Transformasi Digital di Lingkungan NU dan Pesantren, Perlukah?

Sabtu, 11 Desember 2021

\section{Total Pengakses}

- Berdasarkan IP address : 123

- Berdasarkan Klik : 129

Distribusi Pengakses Berdasarkan Waktu (CET/Central European Time Zone) Distribusi Waktu

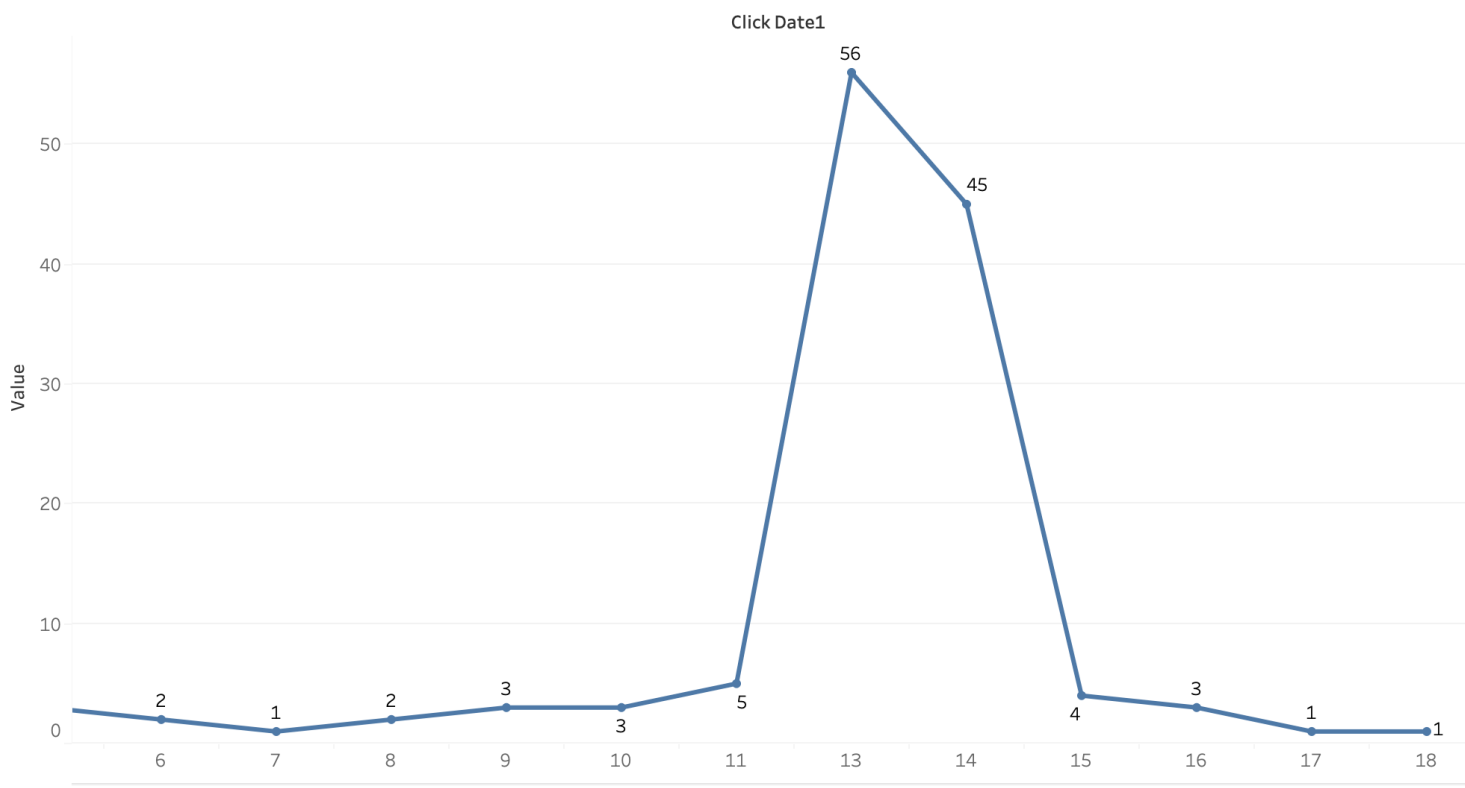

Jenis Perangkat Pengguna

Jenis Perangkat

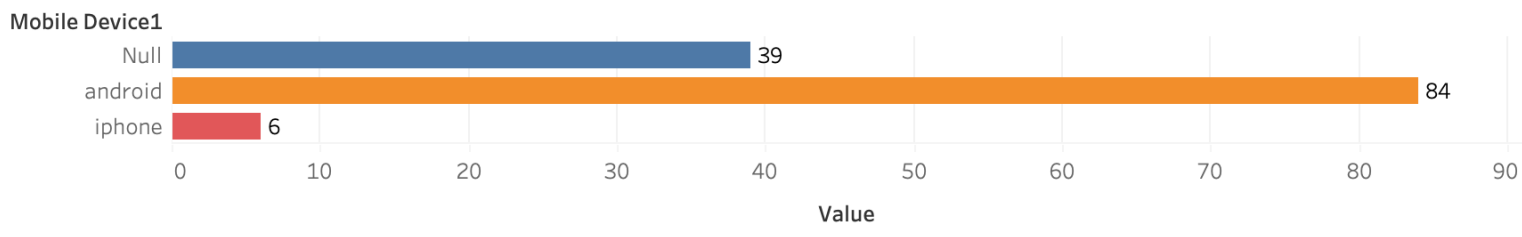




\section{Distribusi Negara Pengakses}

Distribusi Negara

Country1

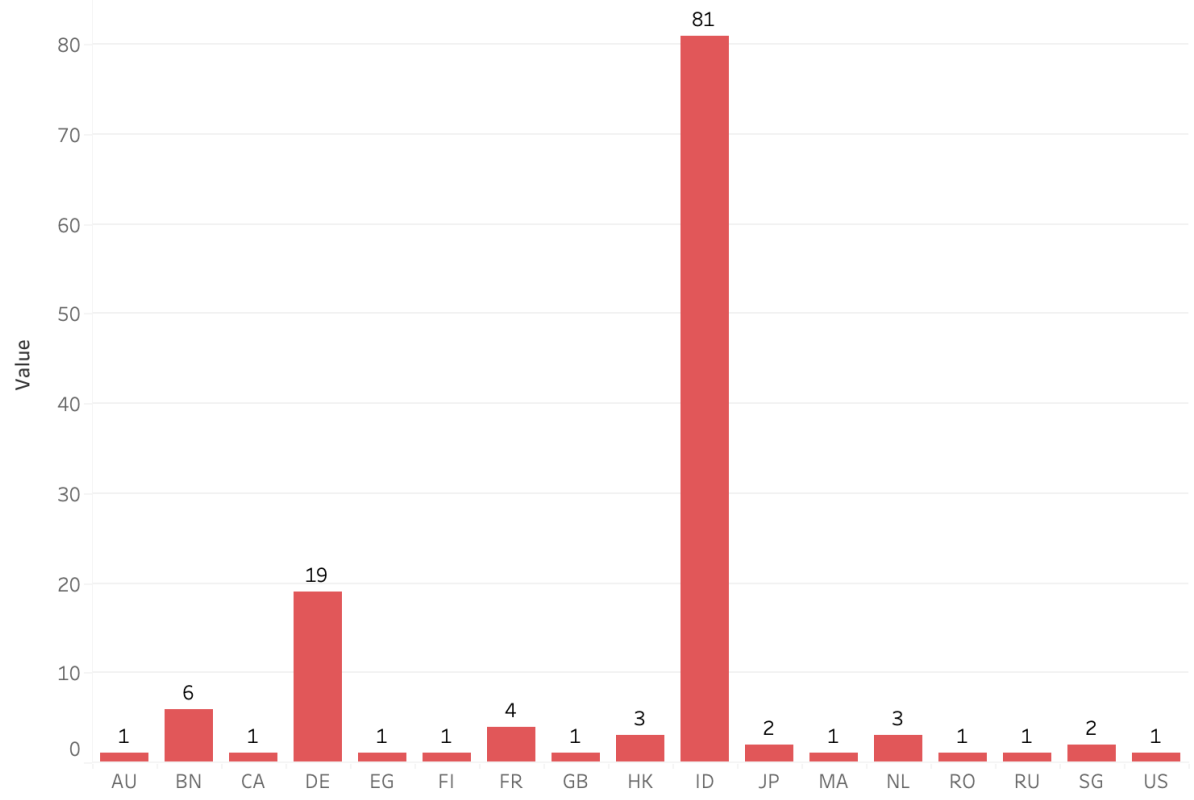

\section{Geografi Negara Pengakses}

Peta Distribusi Negara

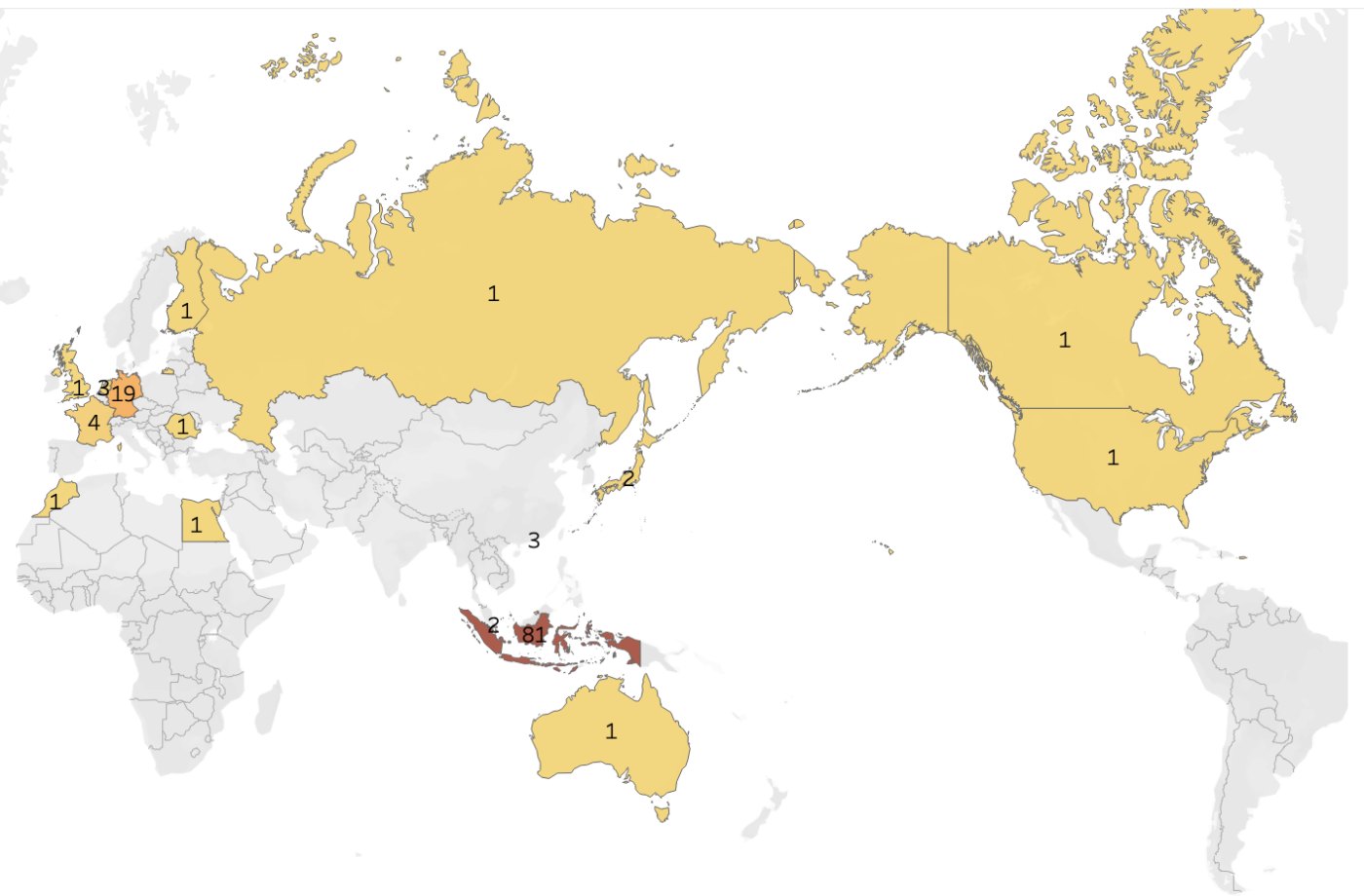


Geografi Negara Pengakses (Eropa)

Peta Distribusi Negara (Eropa)

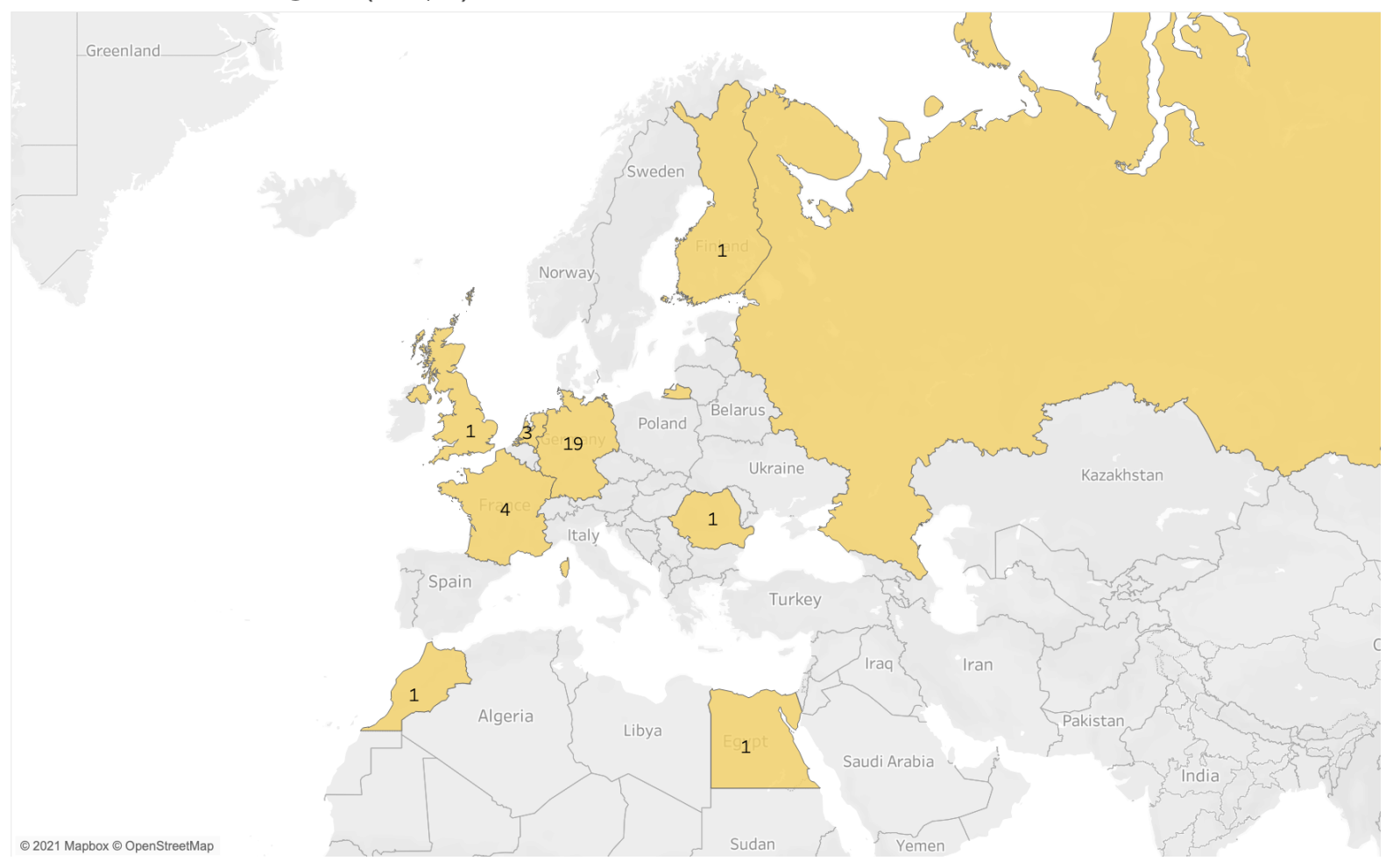

\section{Distribusi Berdasarkan Kota}

Distribusi Kota

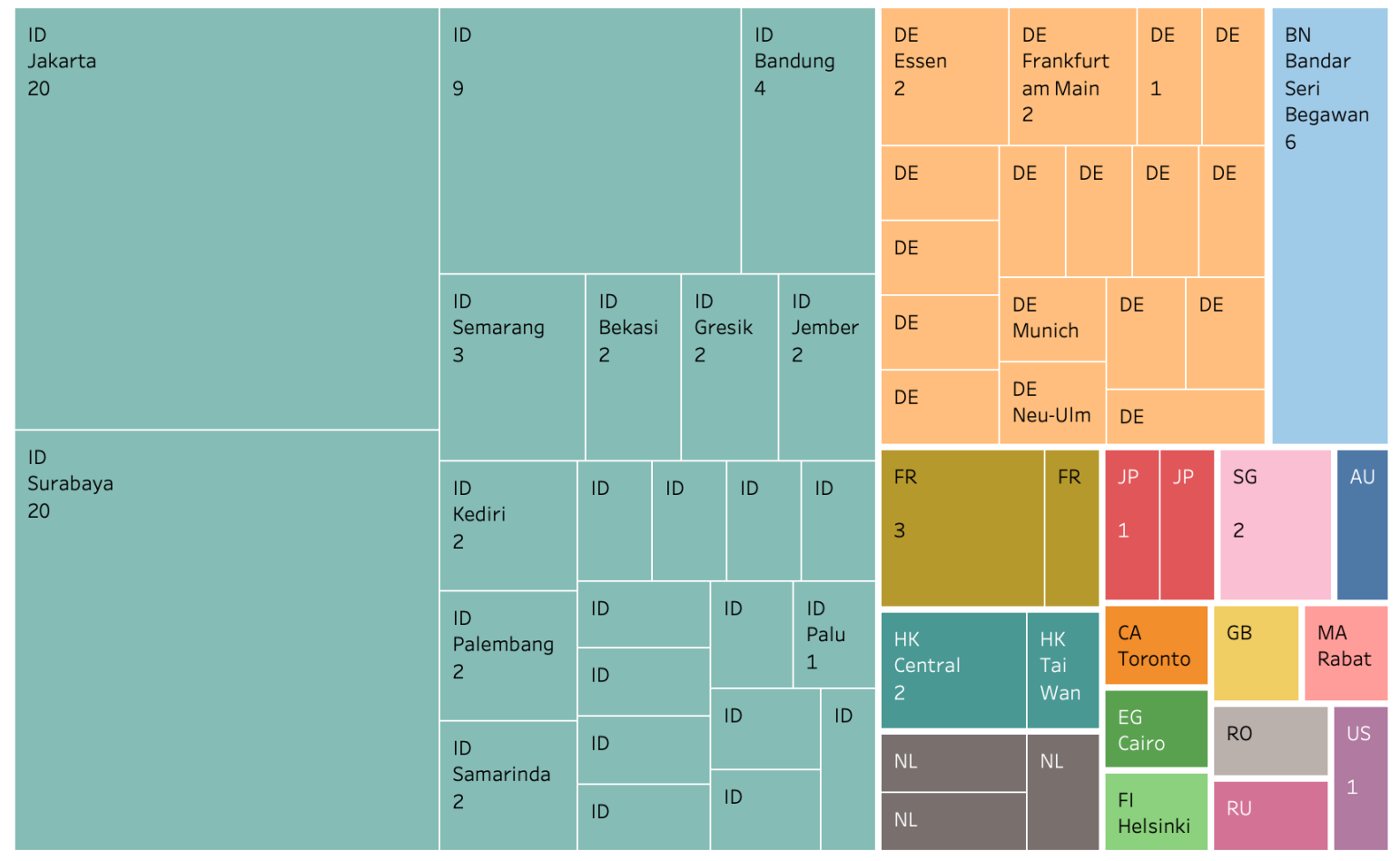




\title{
Analisis Seri \#2
}

\section{Poster Acara}

webinar pra-muktamar

PCINU Sedunia

Seri \#2

Muktamar Ke-34

Nahdlatul Ulama $q$

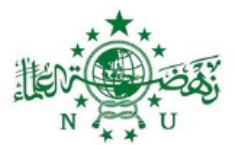

\section{SERATUS TAHUN NAHDLATUL ULAMA:}

\author{
Diplomasi Perdamaian \\ dan Dakwah Internasional NU
}

\section{成}

Ahad, 12 Desember 2021

Zoom Meeting ID: 88504597931

Passcode: muktamar

Youtube

15.30- 17.30 WIB

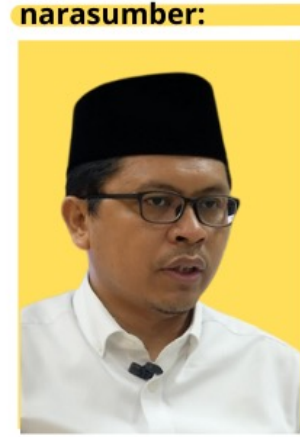

Zuhairi Misrawi

Duta Besar RI untuk Tunisia,

Cendekiawan NU

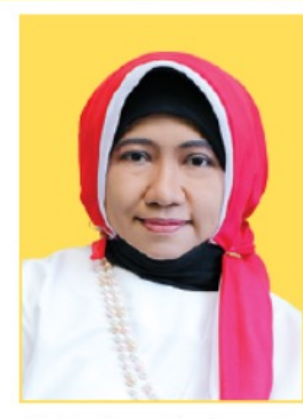

Safira Rosa Machrusah Duta Besar RI untuk Aljazai 2016-2020

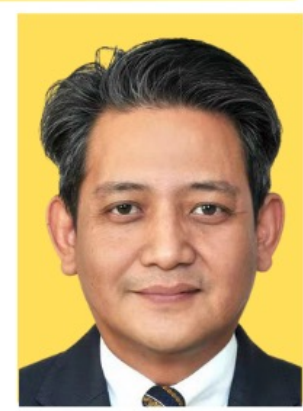

Dino R Kusnadi

Wakil Duta Besar RI untuk RRT merangkap Republik Mongolia

organizer:

PCINU Tiongkok + PCINU UK

media partner:

Contact Person

Fahmi, 085770609022

\section{moderator:}

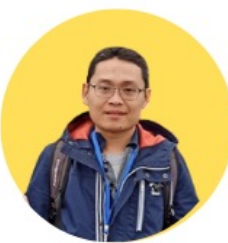

Ahmad Syaifuddin Zuhri PINU Tiongkok / Mahasiswa International Studies CCNU

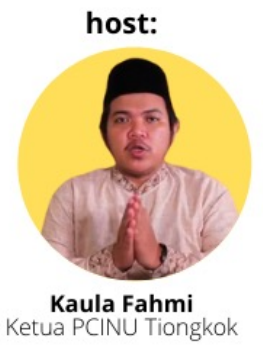


Seratus Tahun Nahdlatul Ulama,

DIPLOMASI PERDAMAIAN \& DAKWAH INTERNASIONAL NU

Ahad, 12 Desember 2021

\section{Total Pengakses}

- Berdasarkan IP address : $\mathbf{7 4}$

- Berdasarkan Klik : 82

Distribusi Pengakses Berdasarkan Waktu (CET/Central European Time Zone) Distribusi Waktu

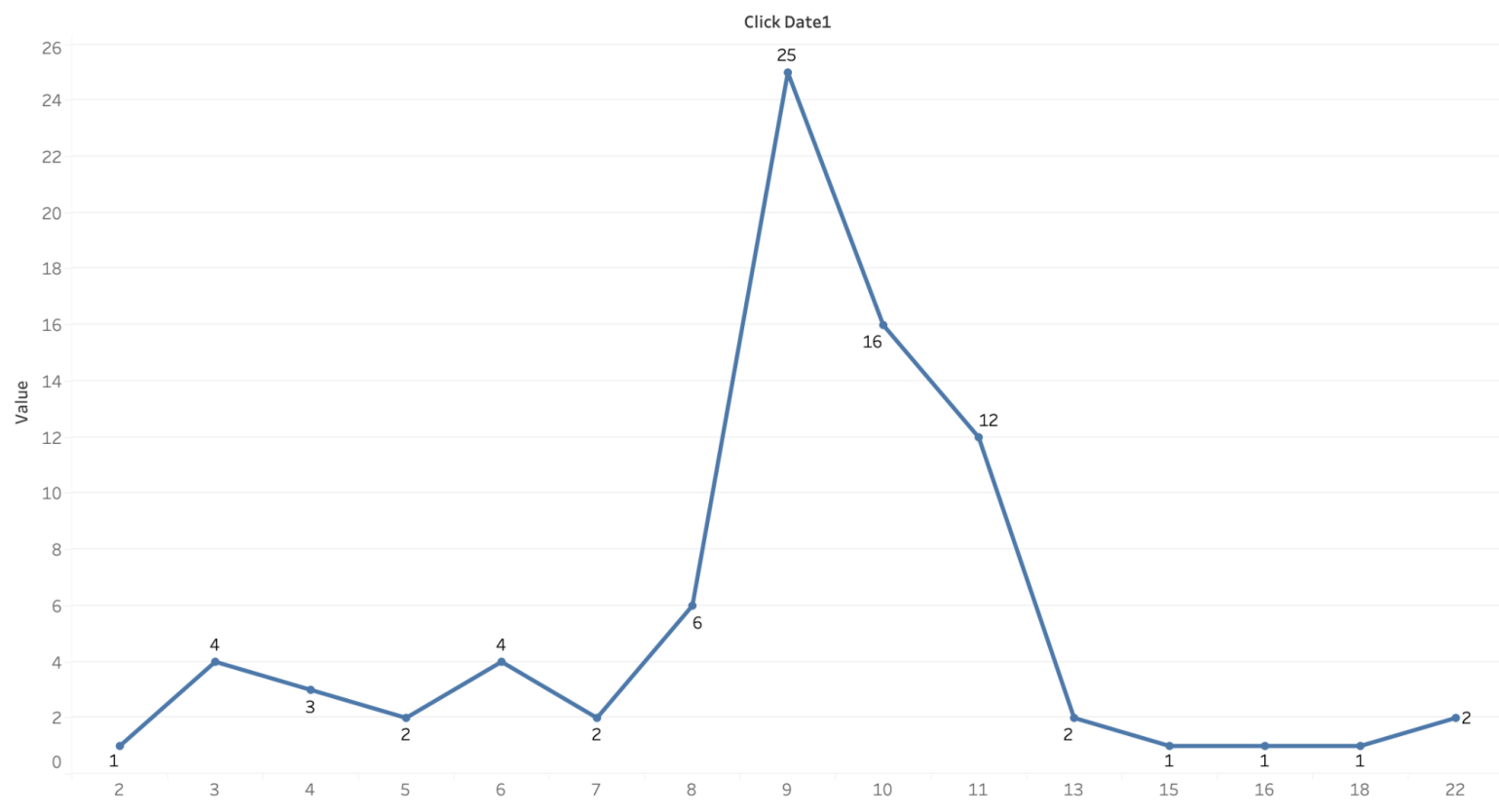

Jenis Perangkat Pengguna

Jenis Perangkat

Mobile Device1

\begin{tabular}{r|r} 
Null & 19 \\
android &
\end{tabular}

iphon

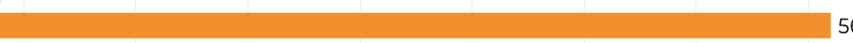

0

15

20

25

30

35

45

50 


\section{Distribusi Negara Pengakses}

Distribusi Negara

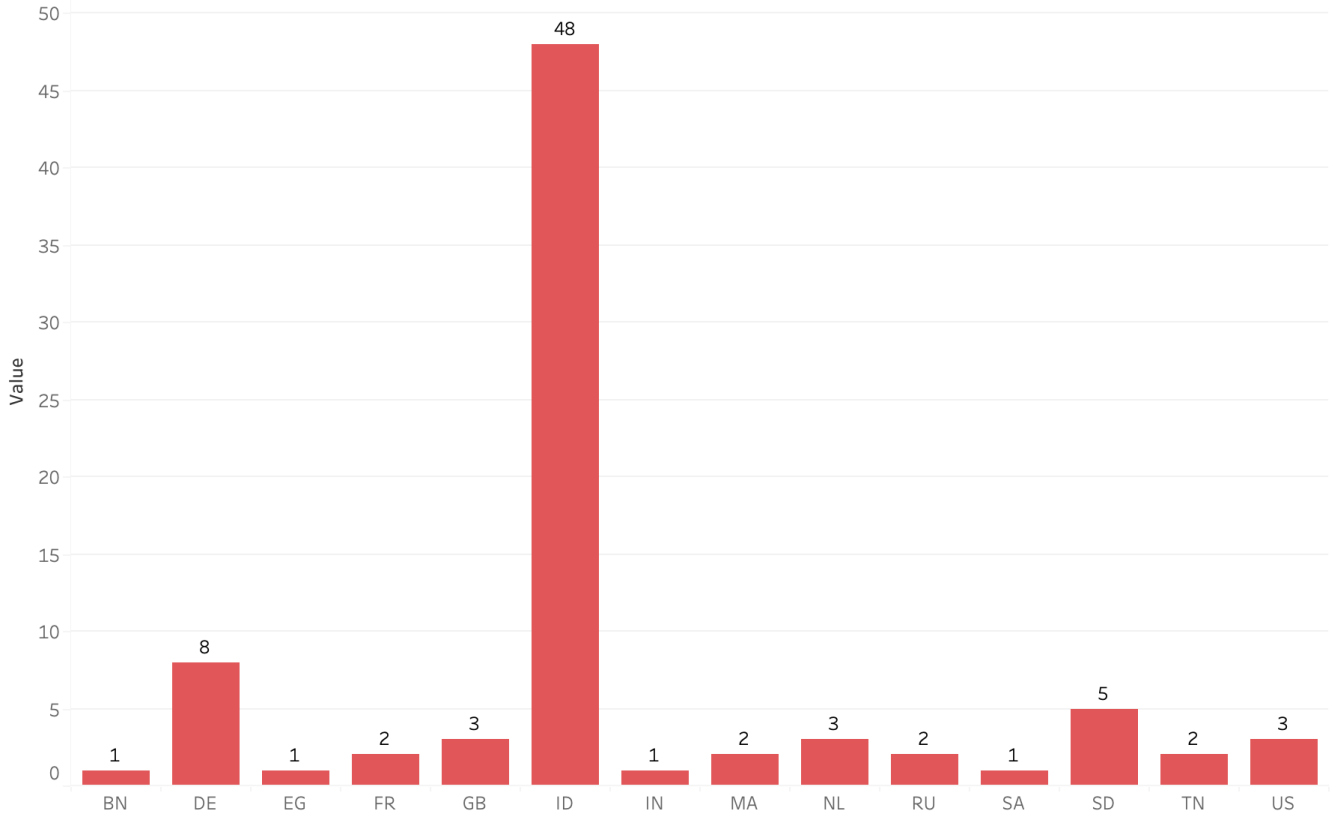

\section{Geografi Negara Pengakses}

Peta Distribusi Negara

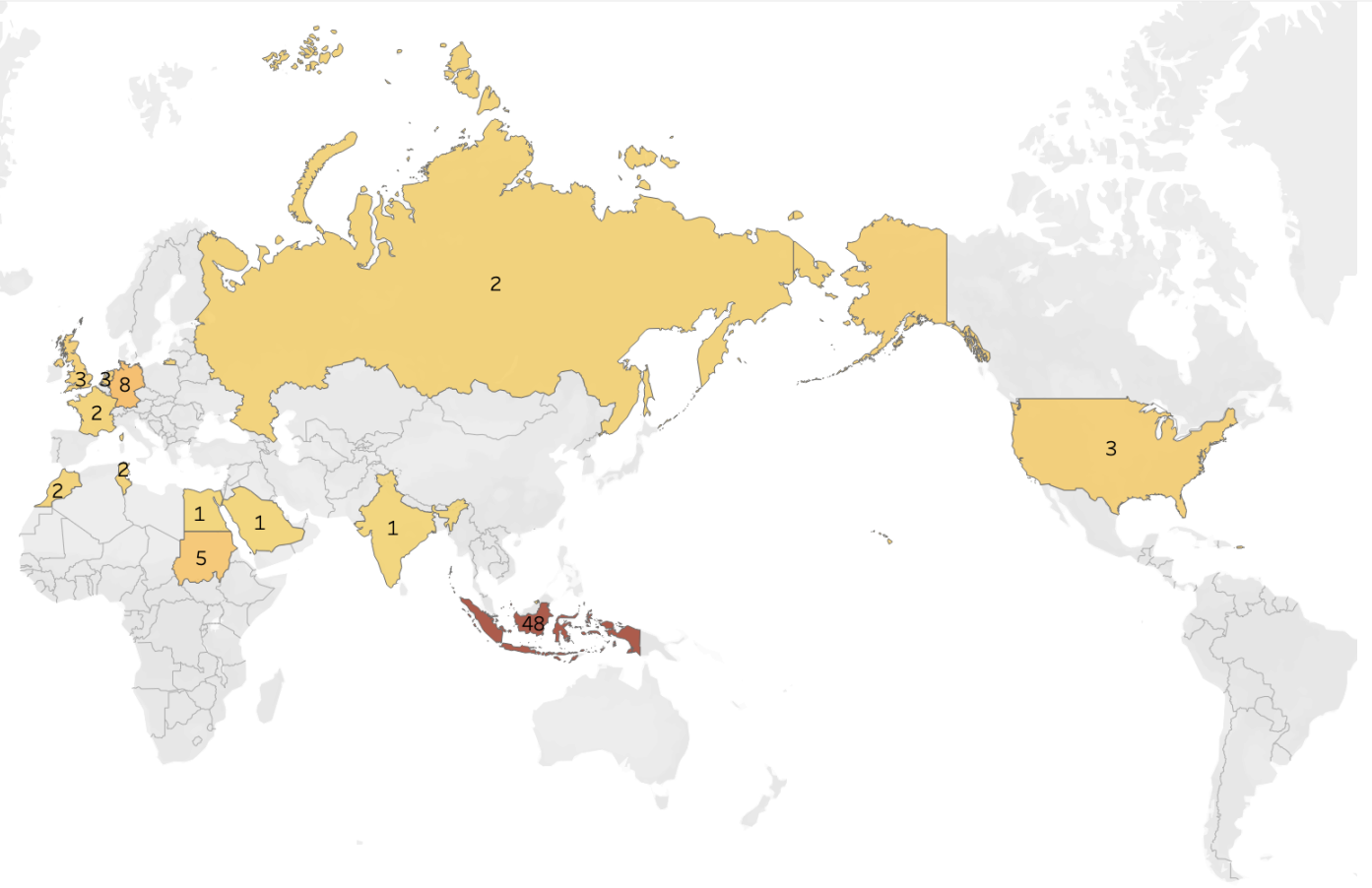


Geografi Negara Pengakses (Eropa)

Peta Distribusi Negara (Eropa)

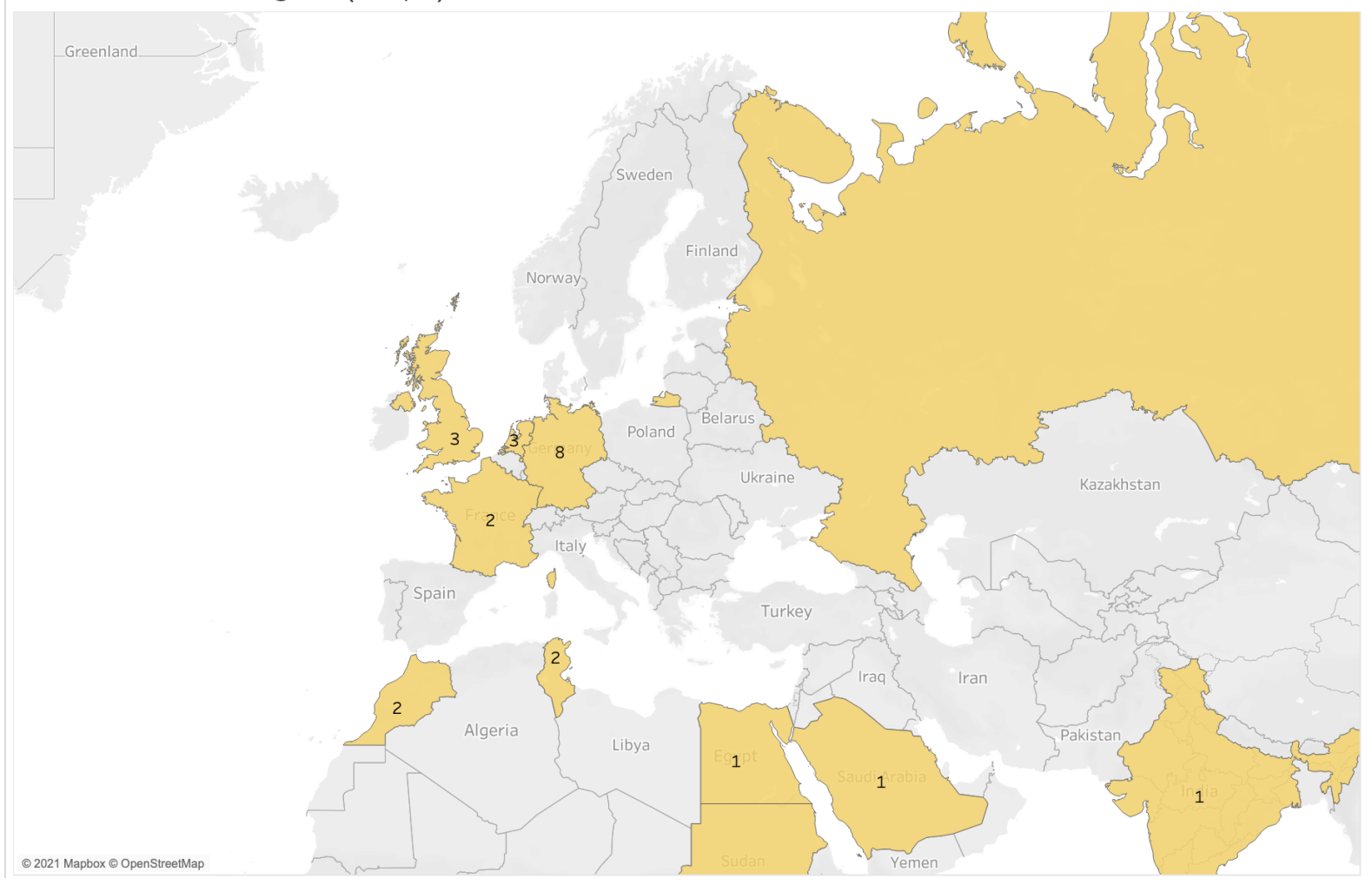

\section{Distribusi Berdasarkan Kota}

Distribusi Kota

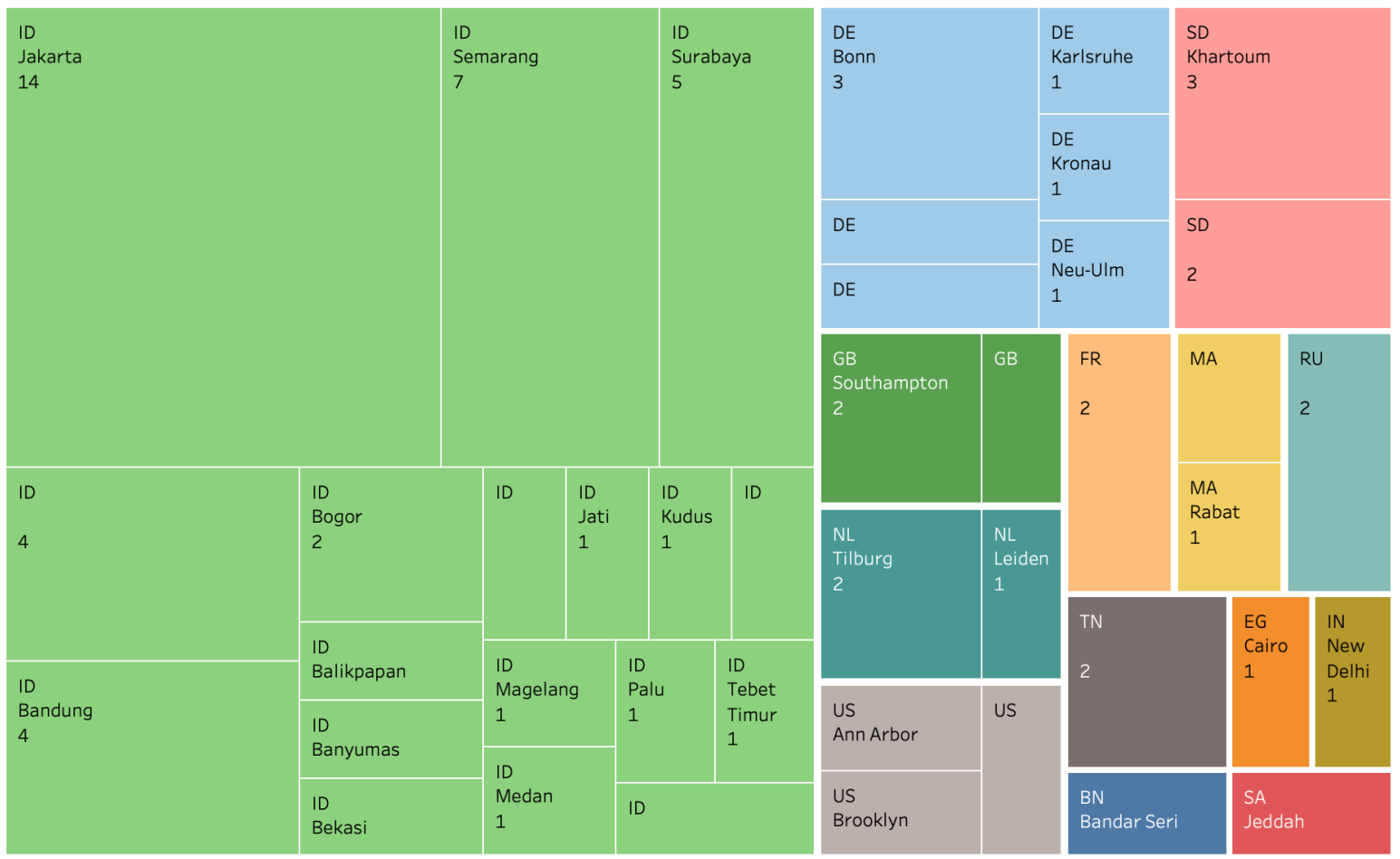




\title{
Analisis Seri \#3
}

\author{
Poster Acara
}

webinar pra-muktamar

PCINU Sedunia

Seri \#3

Muktamar Ke-34

Nahdlatul Ulama $q$

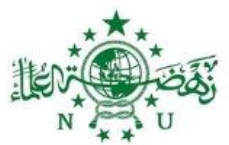

SERATUS TAHUN NAHDLATUL ULAMA:

Pendidikan, Manajemen Data,

dan Transformasi SDM Nahdliyyin

$\begin{array}{lll}\text { i:: Ahad, 12 Desember } 2021 & \text { Zoom Meeting ID: } 88504597931 & \text { Youtube } \\ \text { 19.00-21.00 WIB } & \text { Passcode: muktamar } & \text { LIVE: TVNU }\end{array}$

narasumber:

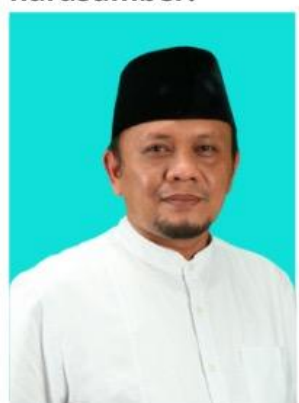

Dr. M. Hasan Chabibie PIt. Ketum PP MATAN NU

Kepala Pusdatin

Kemendikbud

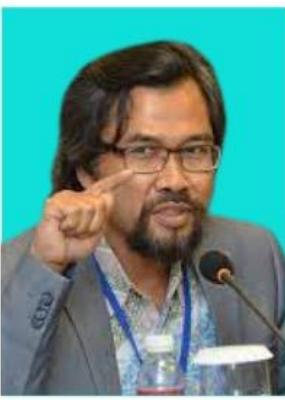

Ahmad Munjid, Ph.D

Dosen FIB UGM,

Alumni Temple University USA

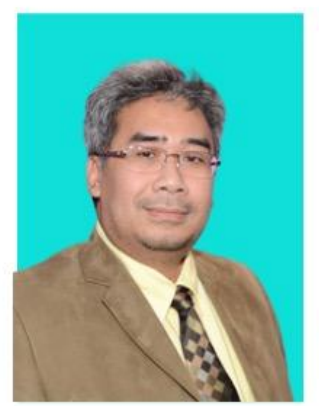

Surya Mahdi, Ph.D Wakil Rais Syuriah PCI Dosen School of Management University of Bristol UK

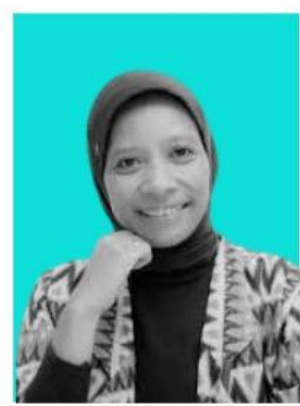

Sidrotun Naim, Ph.D Alumni Harvard University John F. Kennedy School of Government

organizer:

PCINU United Kingdom

media partner:

điviư nuonline

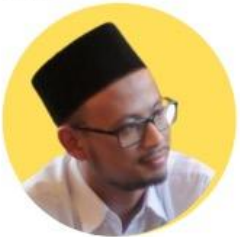

host:

M. Rodlin Billah Ketua PCINU Jerman

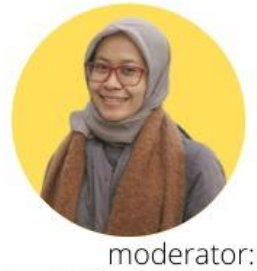

Ayu Sajida Da'ad Arin University of Southampton UK 
Seratus Tahun Nahdlatul Ulama,

Pendidikan, Manajemen Data, dan Transformasi SDM Nahdliyyin.

Ahad, 12 Desember 2021

\section{Total Pengakses}

- Berdasarkan IP address : 133

- Berdasarkan Klik : 220

Distribusi Pengakses Berdasarkan Waktu (CET/Central European Time Zone) Distribusi Waktu

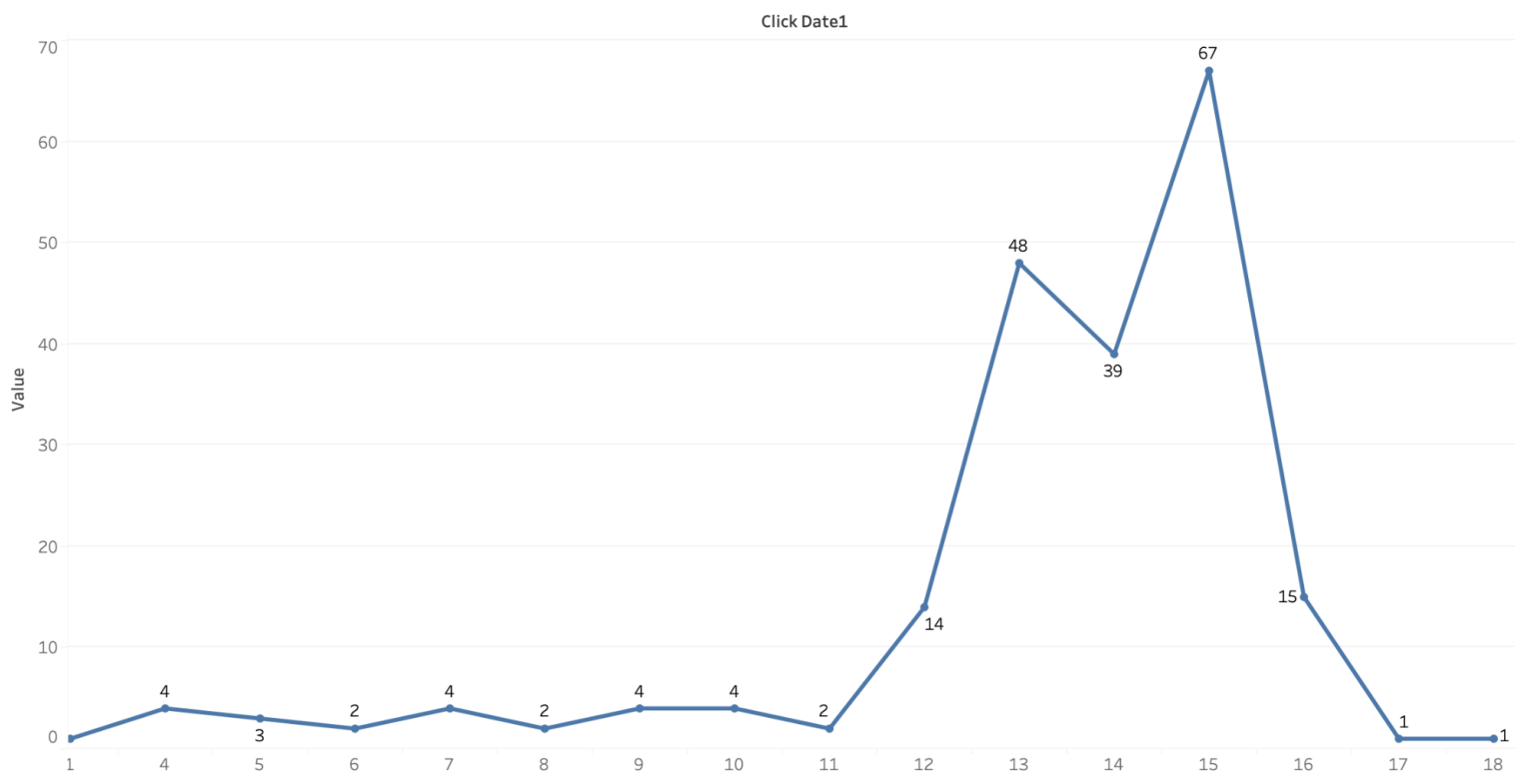

Jenis Perangkat Pengguna

Jenis Perangkat

Mobile Device1

android

(10)

iphone

010

20

30

40

50

Value

102 


\section{Distribusi Negara Pengakses}

Distribusi Negara

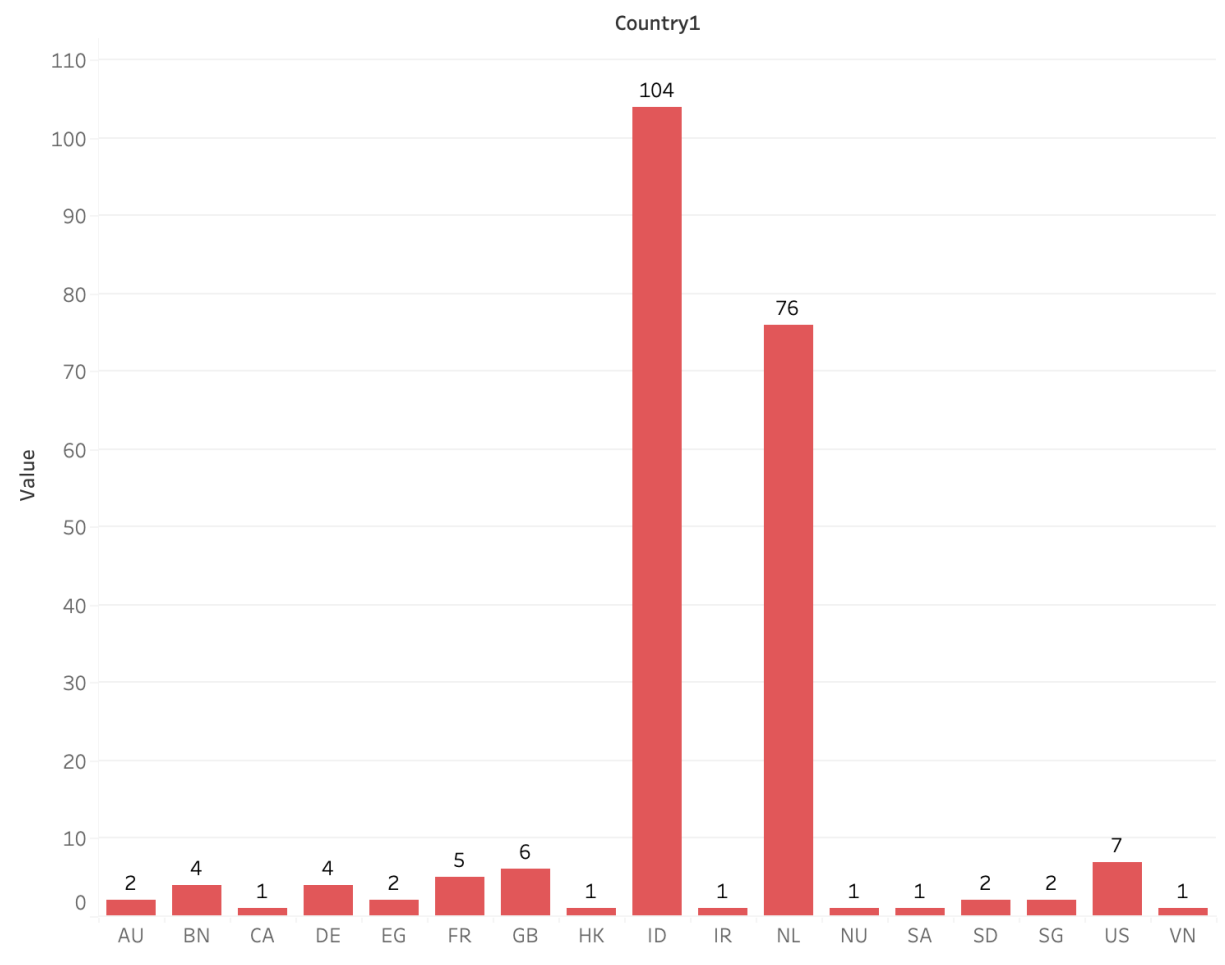

\section{Geografi Negara Pengakses}

Peta Distribusi Negara

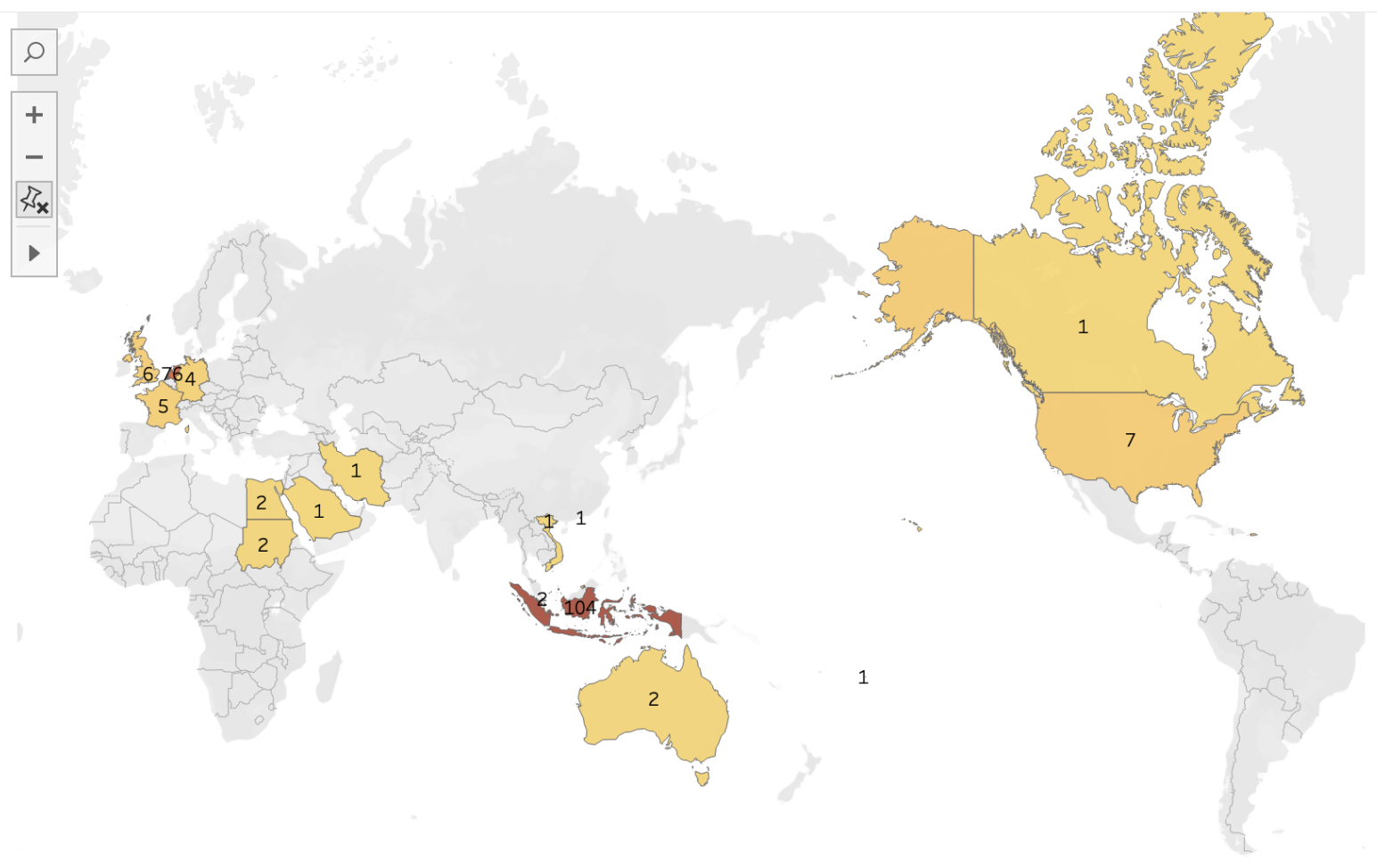


Geografi Negara Pengakses (Eropa)

Peta Distribusi Negara (Eropa)

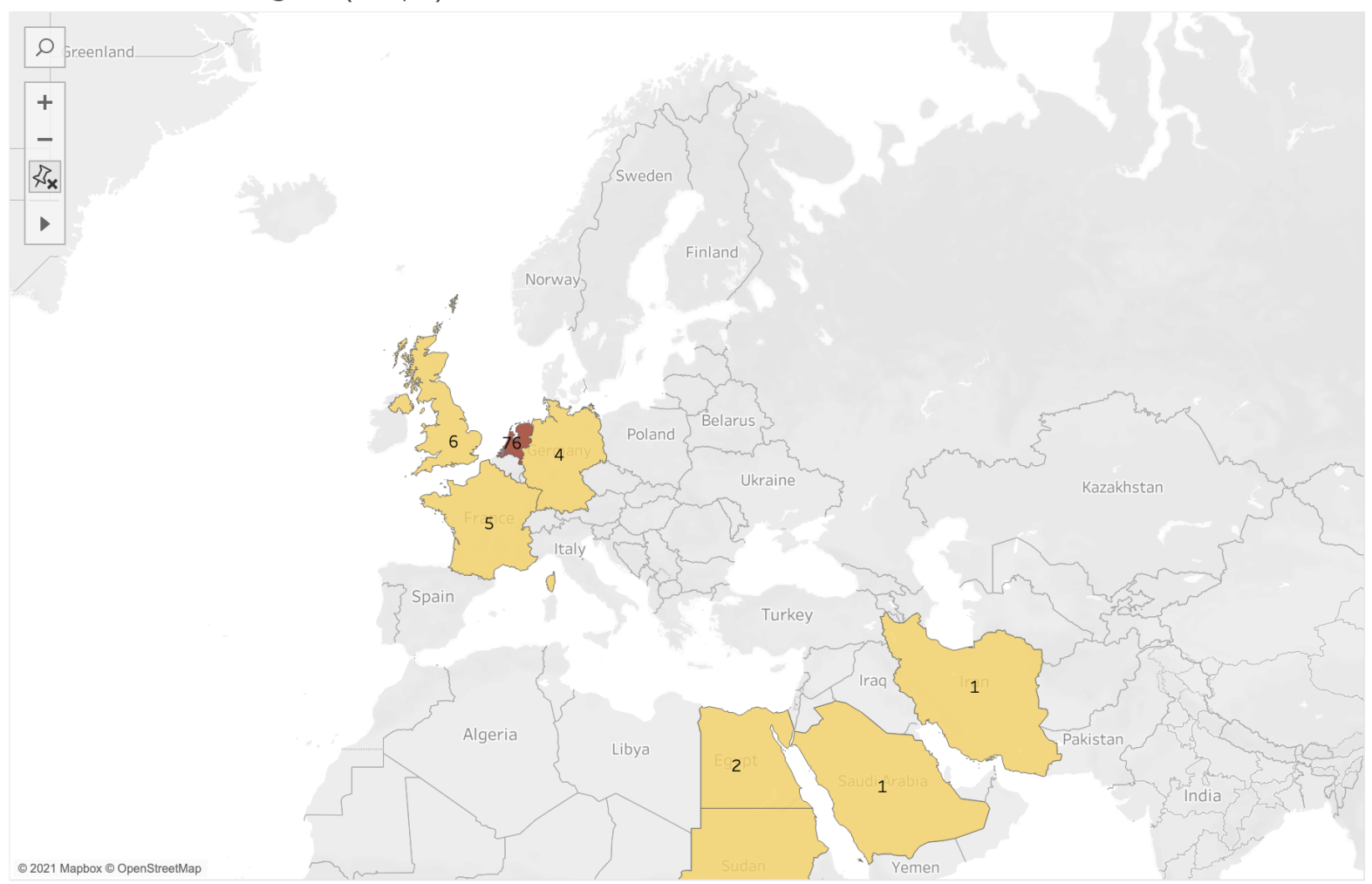

\section{Distribusi Berdasarkan Kota}

Distribusi Kota

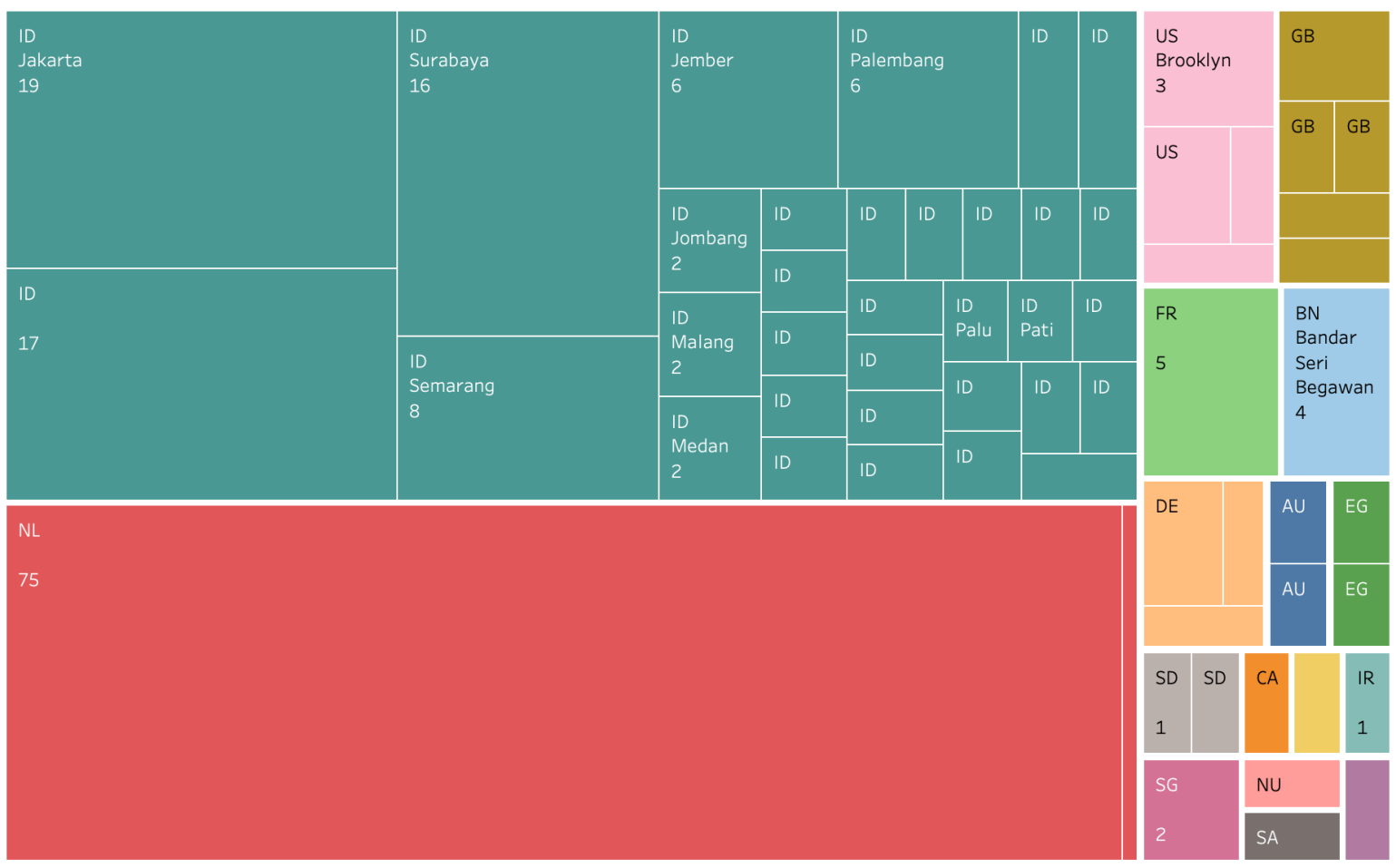




\section{Analisis Seri \#4}

\section{Poster Acara}

webinar pra-muktamar

PCINU Sedunia

Seri \#4

Muktamar Ke-34

Nahdlatul Ulama $q$

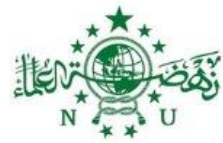

\section{MENUJU ABAD KE-2 NAHDLATUL ULAMA:}

Industri Halal \& Ekonomi Digital

Bagaimana Pesantren dan NU mempersiapkannya?

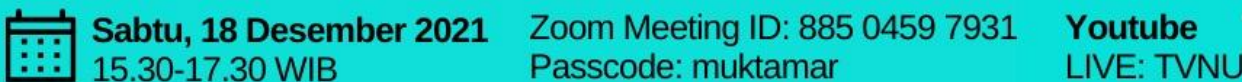

\section{pengantar:}

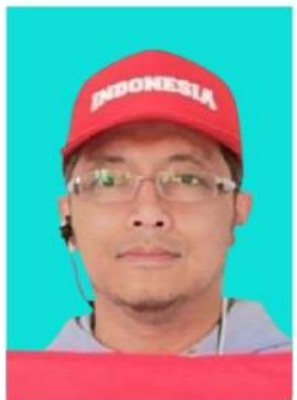

Shandy Adiguna

Ketua PCINU United Kingdom praktisi ekonomi internasional

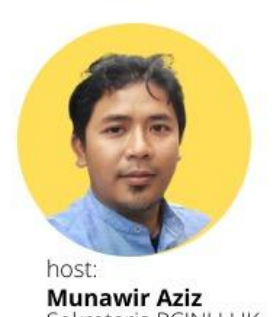

Munawir Aziz

Sekretaris PCINU UK narasumber:

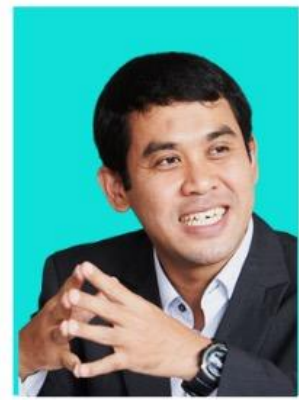

Ayang Utriza Yakin, Ph.D Peneliti di SciencesPo Bourdeaux dan UCLouvain, PCINÚ Belgia

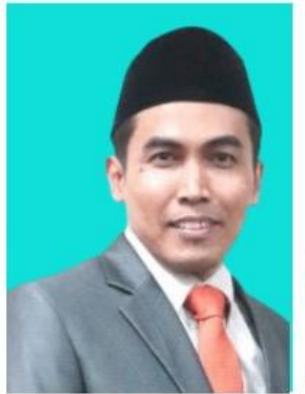

Dr. ret.nat Jaenal Effendi Ketua Lembaga Perekonom Bogor/IPB

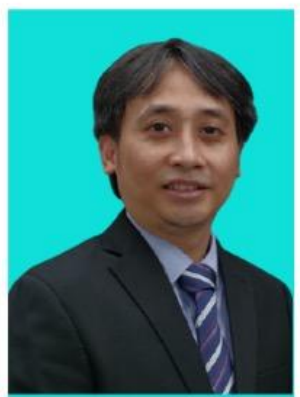

Teguh Dartanto, Ph.D Dekan FEB Universitas Indonesiá
Alumni PCINU Jepang

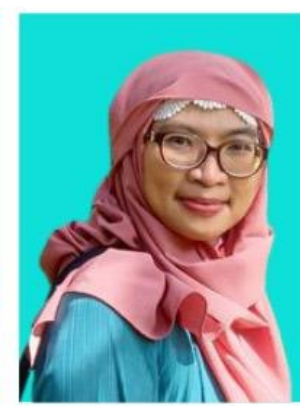

Sitta Rosdaniah Ph.D Kabid Analisis Ekonomi dan Sektor Industri Kementeria
BUMN, Alumni PCINU ANZ

organizer:

\section{PCINU United Kingdom media partner: \\ बiṿu nuoline}


Menuju Abad Ke-2 Nahdlatul Ulama,

Digital Economy dan Halal Industri; Bagaimana Pesantren dan NU mempersiapkan?

Sabtu, 18 Desember 2021

Total Pengakses

- Berdasarkan IP address : 94

- Berdasarkan Klik : 123

Distribusi Pengakses Berdasarkan Waktu (CET/Central European Time Zone) Distribusi Waktu

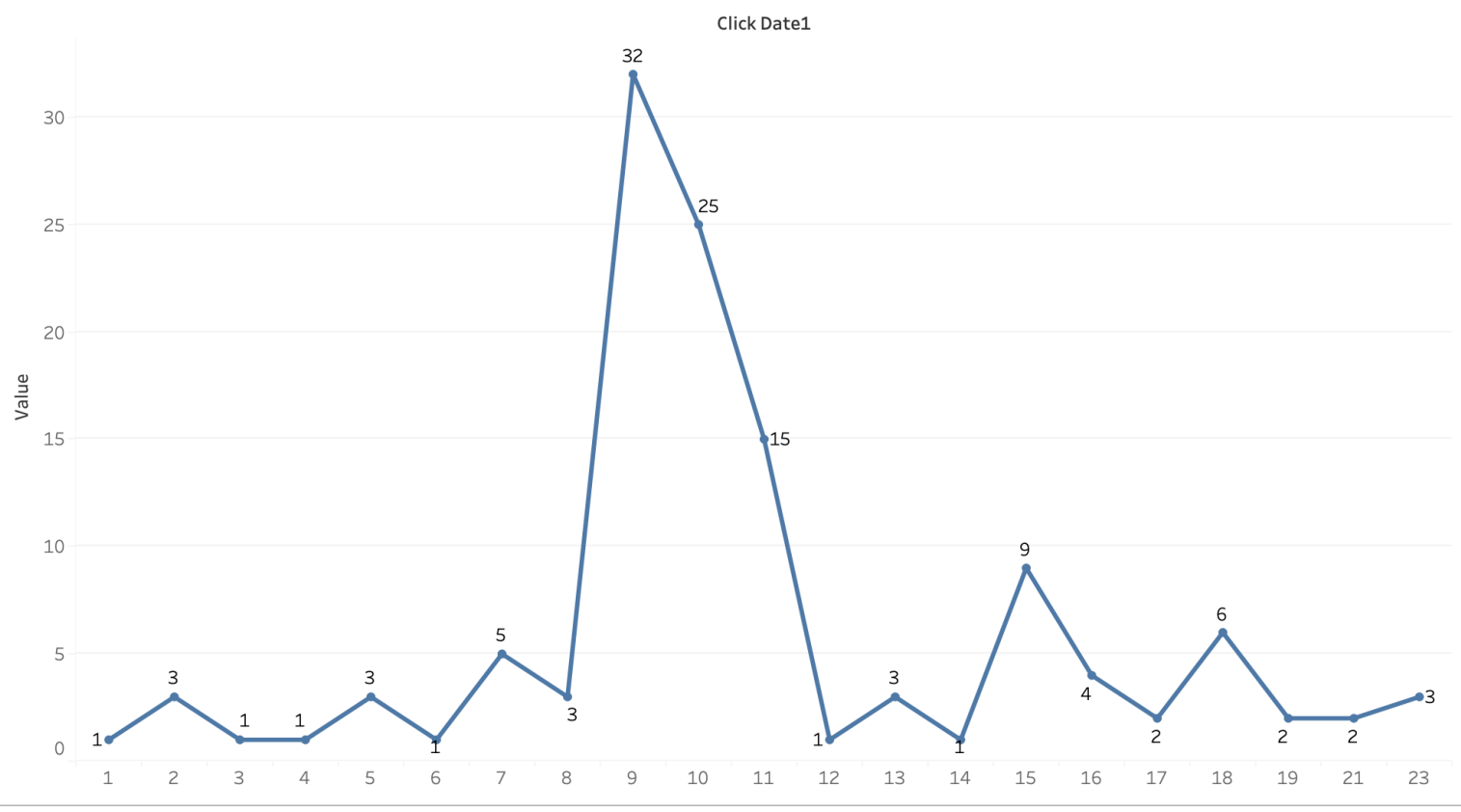

Jenis Perangkat Pengguna

Jenis Perangkat

Mobile Device1

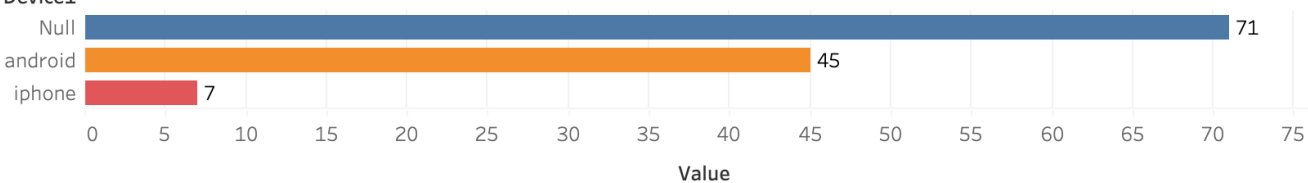




\section{Distribusi Negara Pengakses}

Distribusi Negara

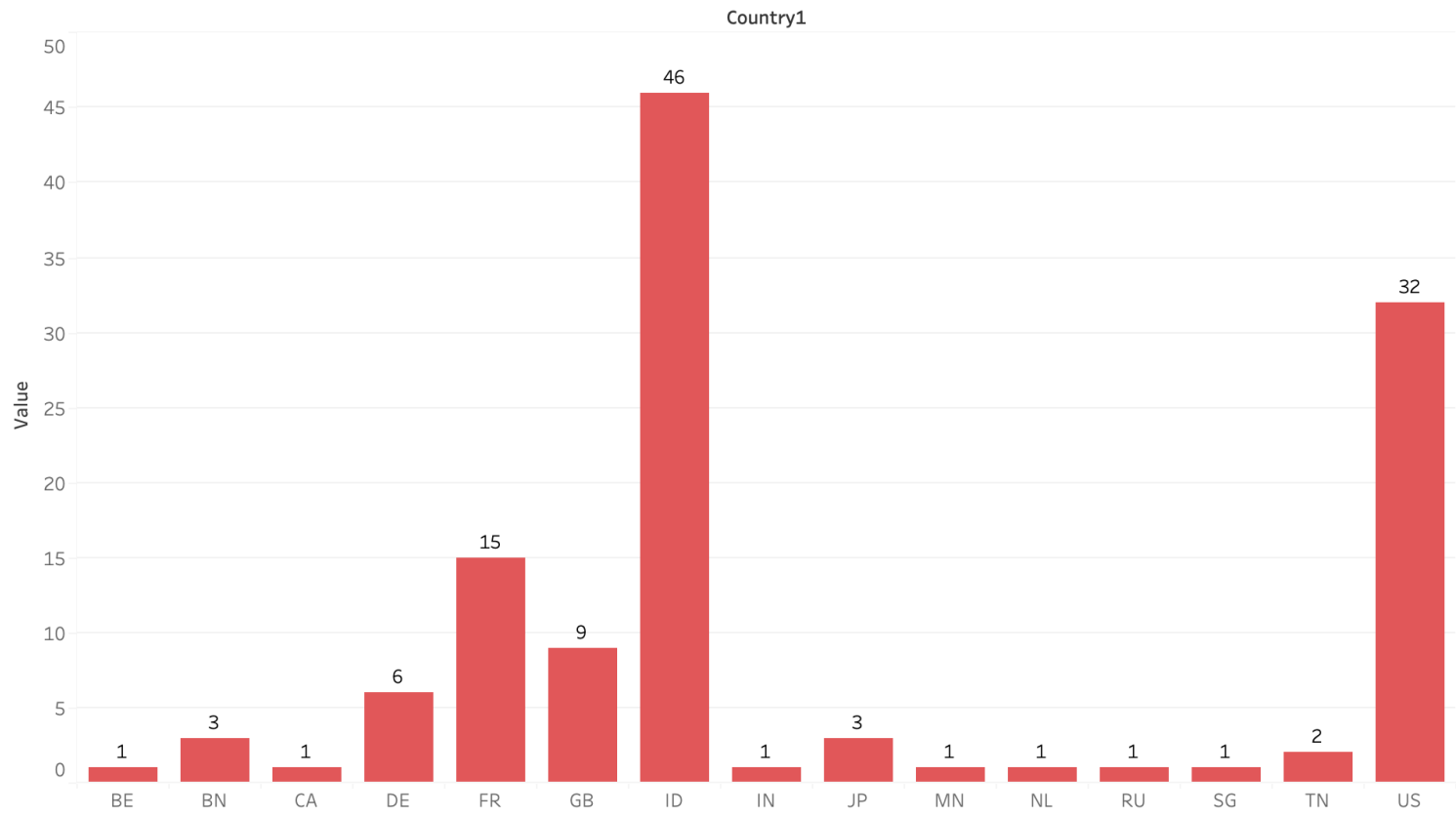

\section{Geografi Negara Pengakses}

Peta Distribusi Negara

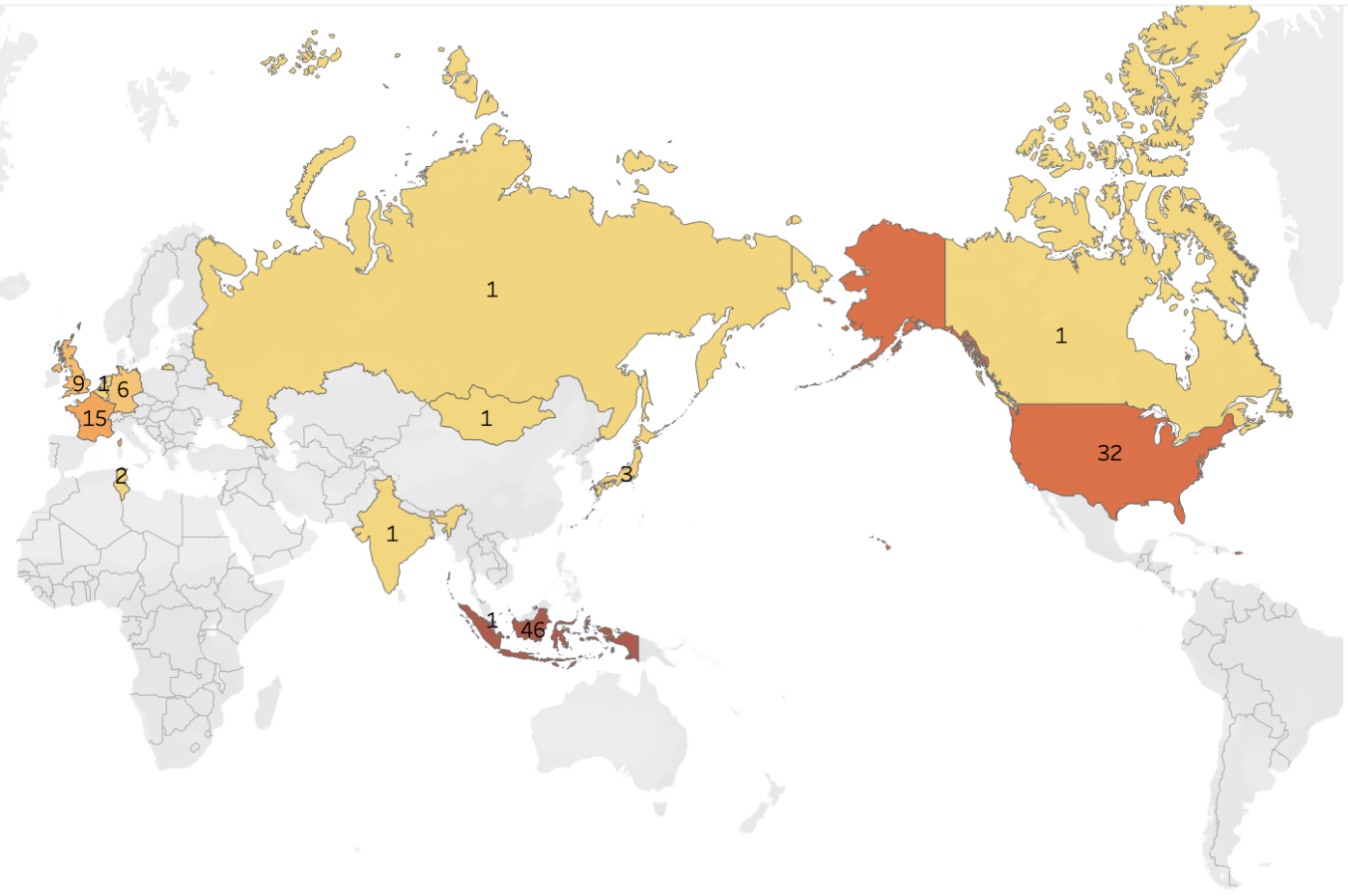


Geografi Negara Pengakses (Eropa)

Peta Distribusi Negara (Eropa)

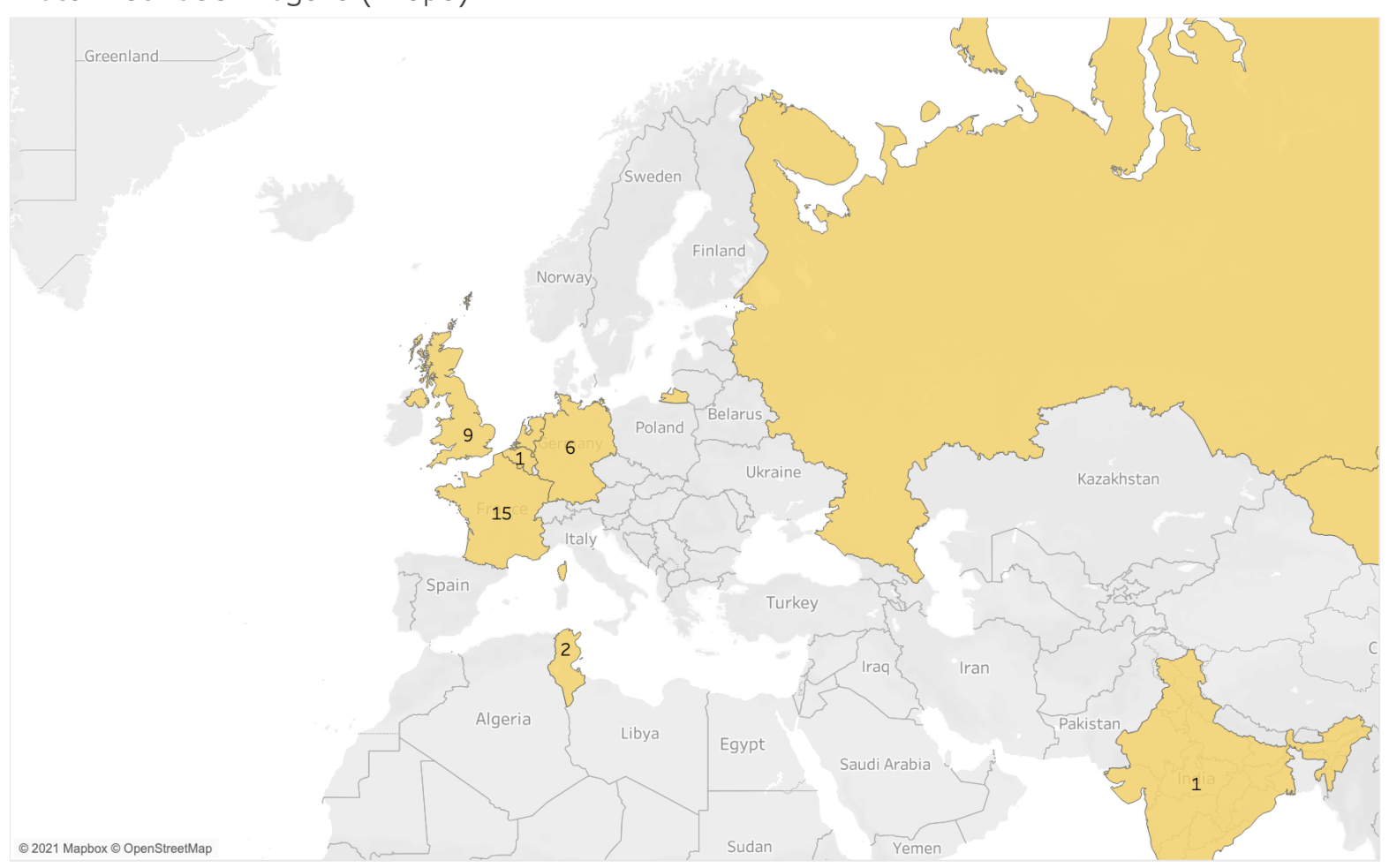

\section{Distribusi Berdasarkan Kota}

Distribusi Kota

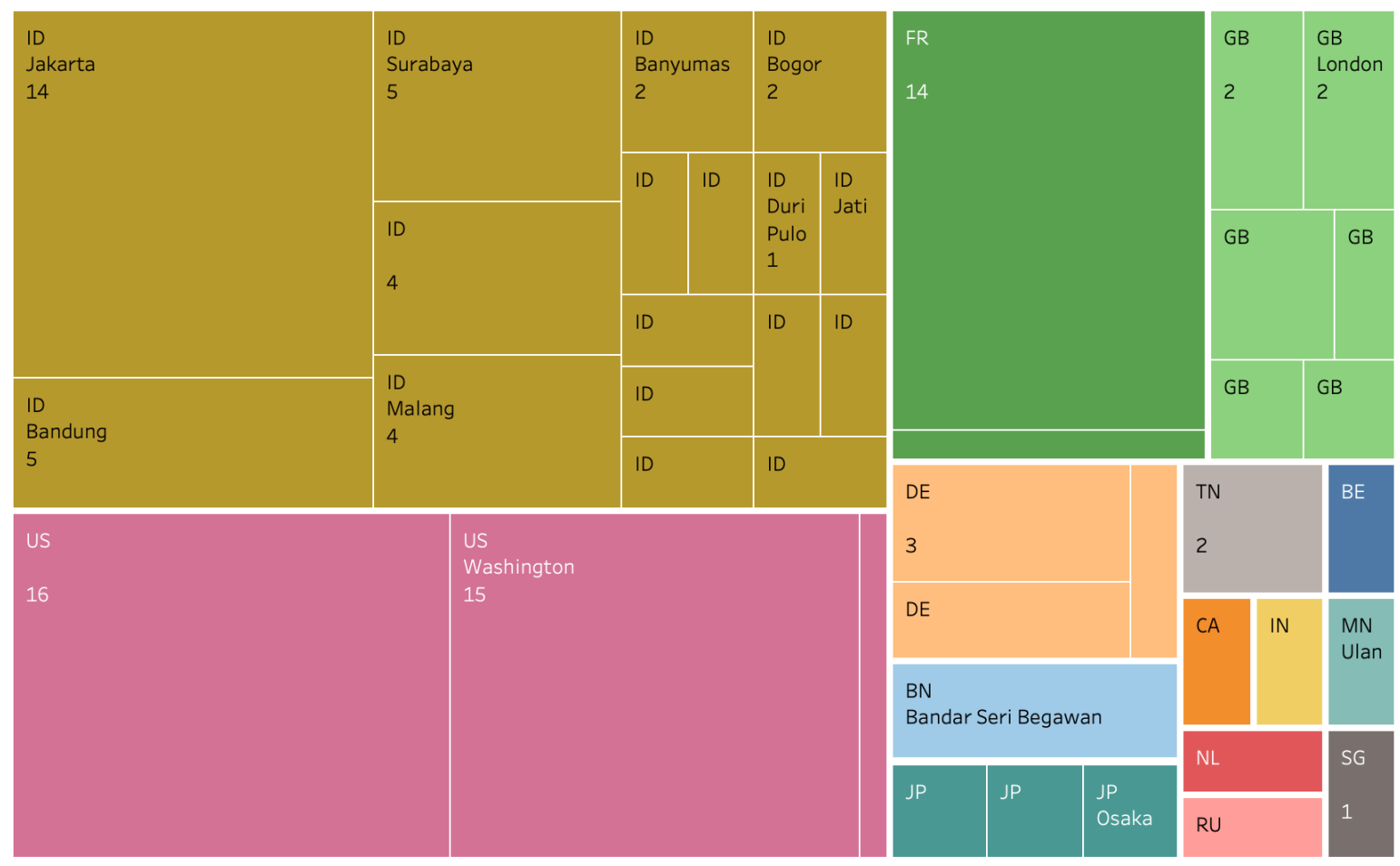




\section{Analisis Seri \#5}

\section{Poster Acara}

\section{Webinar PCI NU se-Dunia menuju
Muktamar NU ke-34}
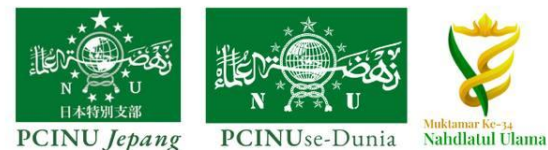

Seri \#5: Climate Change dan Energy

Peran NU dalam menjawab Tantangan Perubahan Iklim

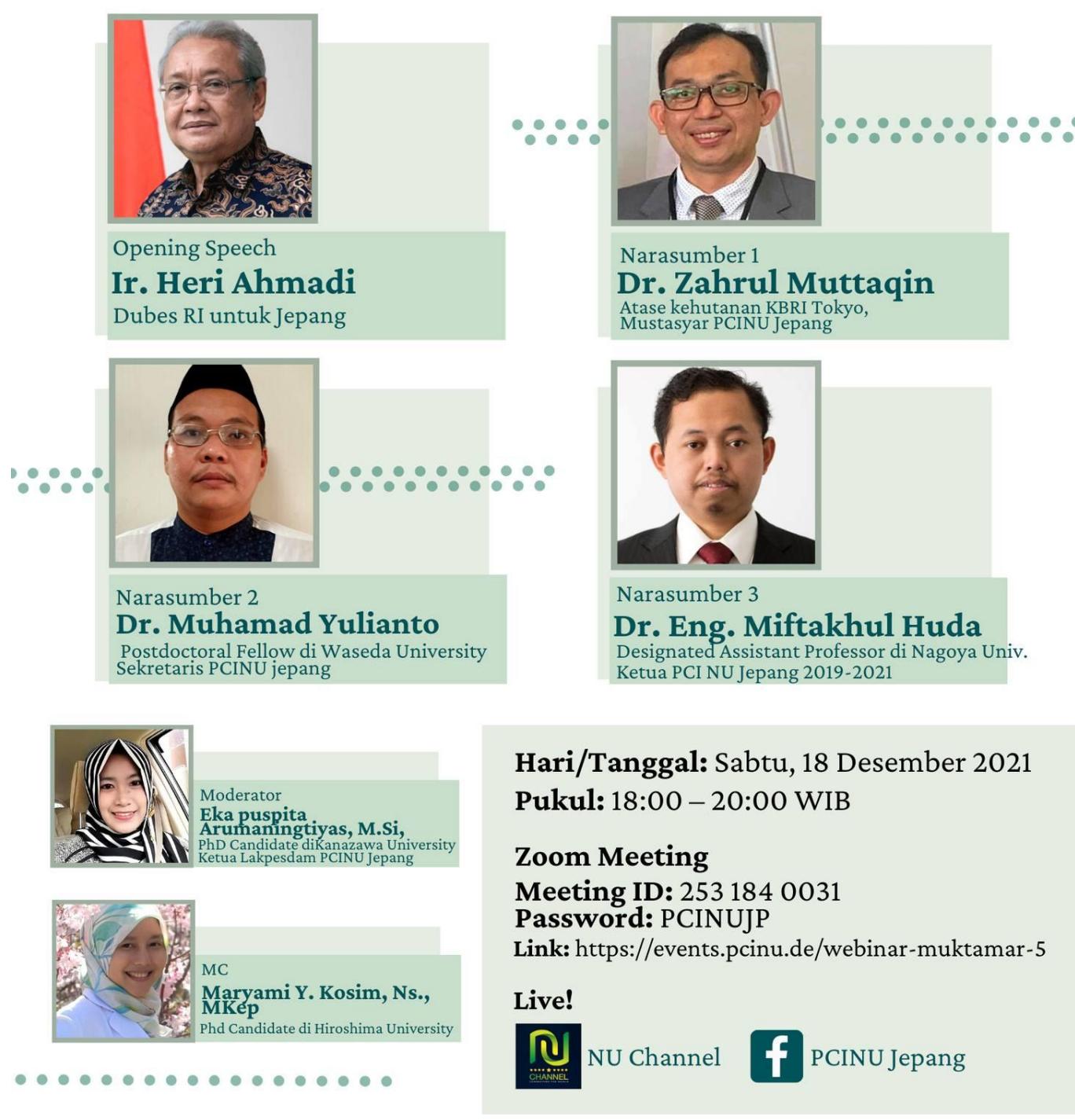


Menuju Abad Ke-2 Nahdlatul Ulama,

Peran NU dalam Menjawab Tantangan Perubahan Iklim

Sabtu, 18 Desember 2021

\section{Total Pengakses}

- Berdasarkan IP address : 86

- Berdasarkan Klik : 93

Distribusi Pengakses Berdasarkan Waktu (CET/Central European Time Zone) Distribusi Waktu

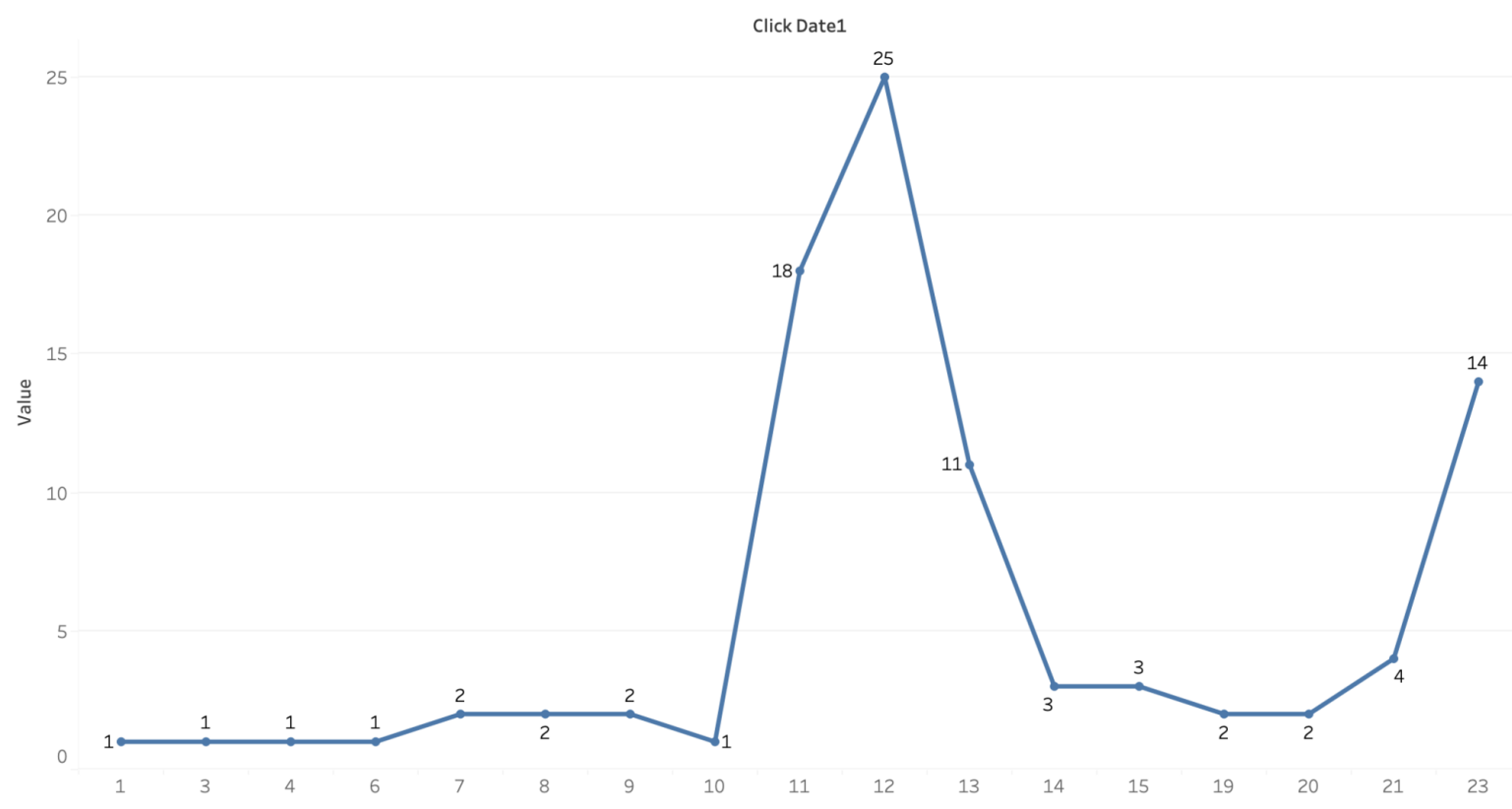

Jenis Perangkat Pengguna

Jenis Perangkat

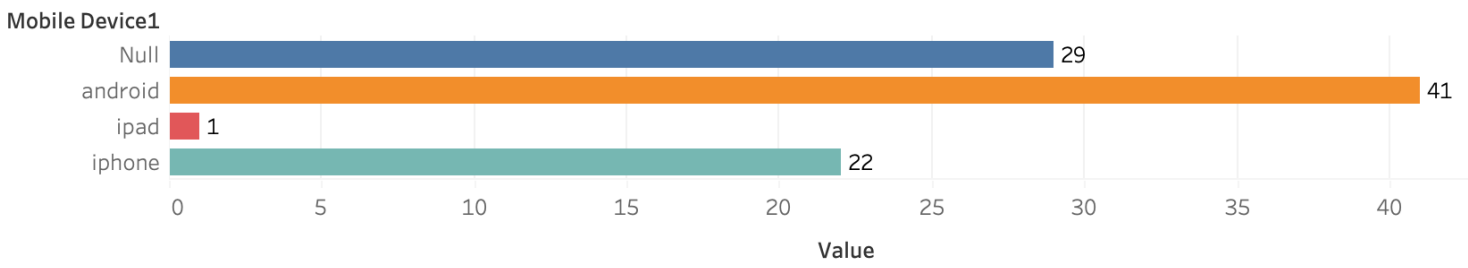




\section{Distribusi Negara Pengakses}

Distribusi Negara

Country1

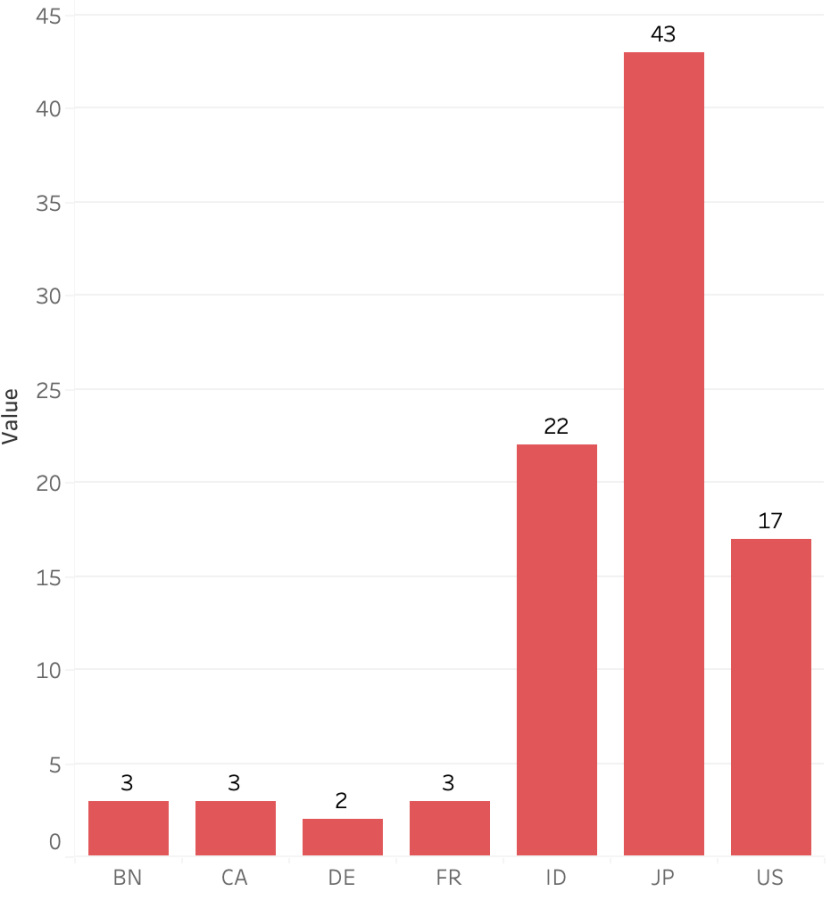

\section{Geografi Negara Pengakses}

Peta Distribusi Negara

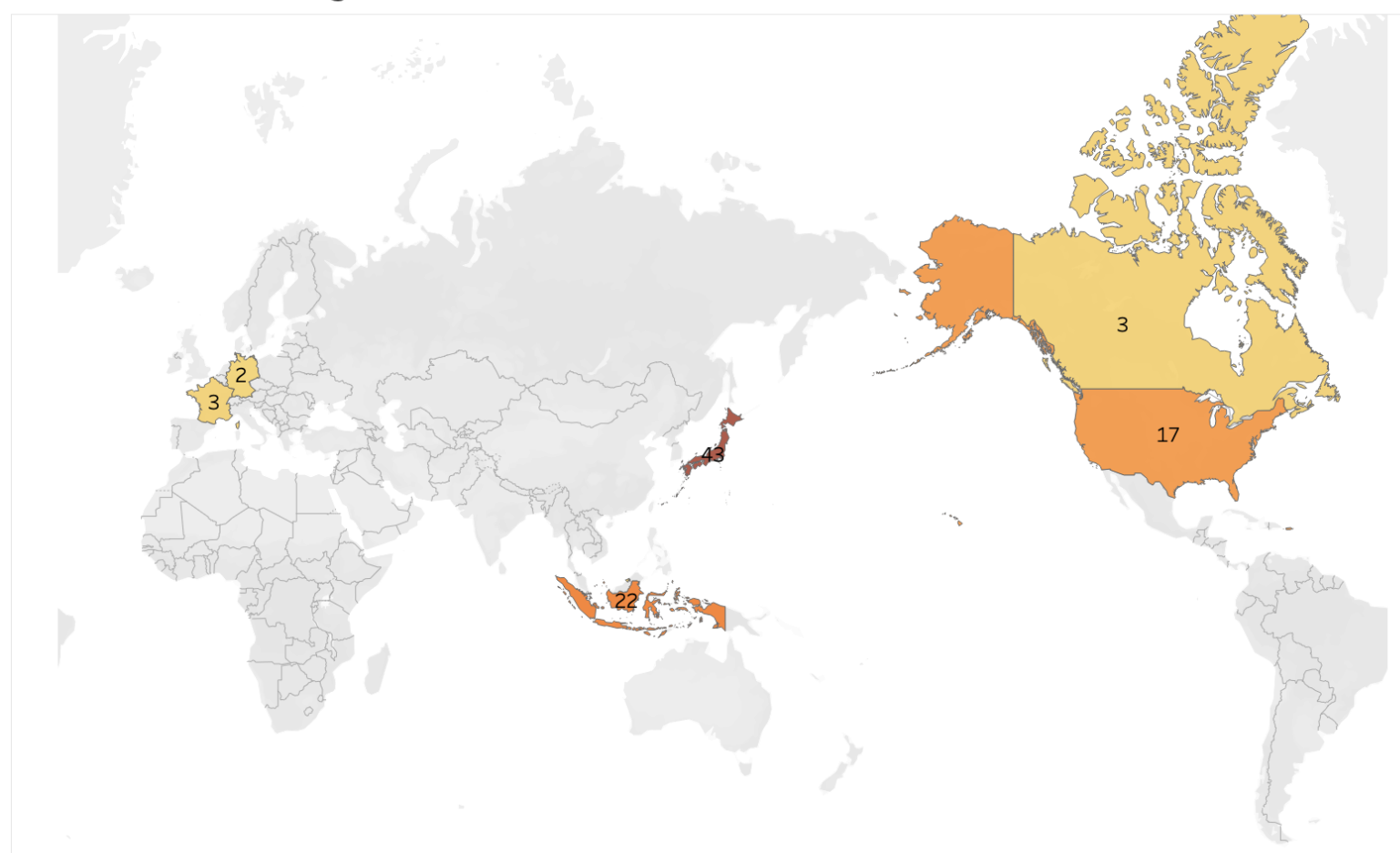


Geografi Negara Pengakses (Eropa)

Peta Distribusi Negara (Eropa)

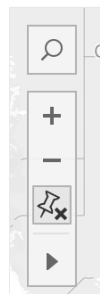

$\odot 2021$ Mapbox $\odot$ OpenStreetMap

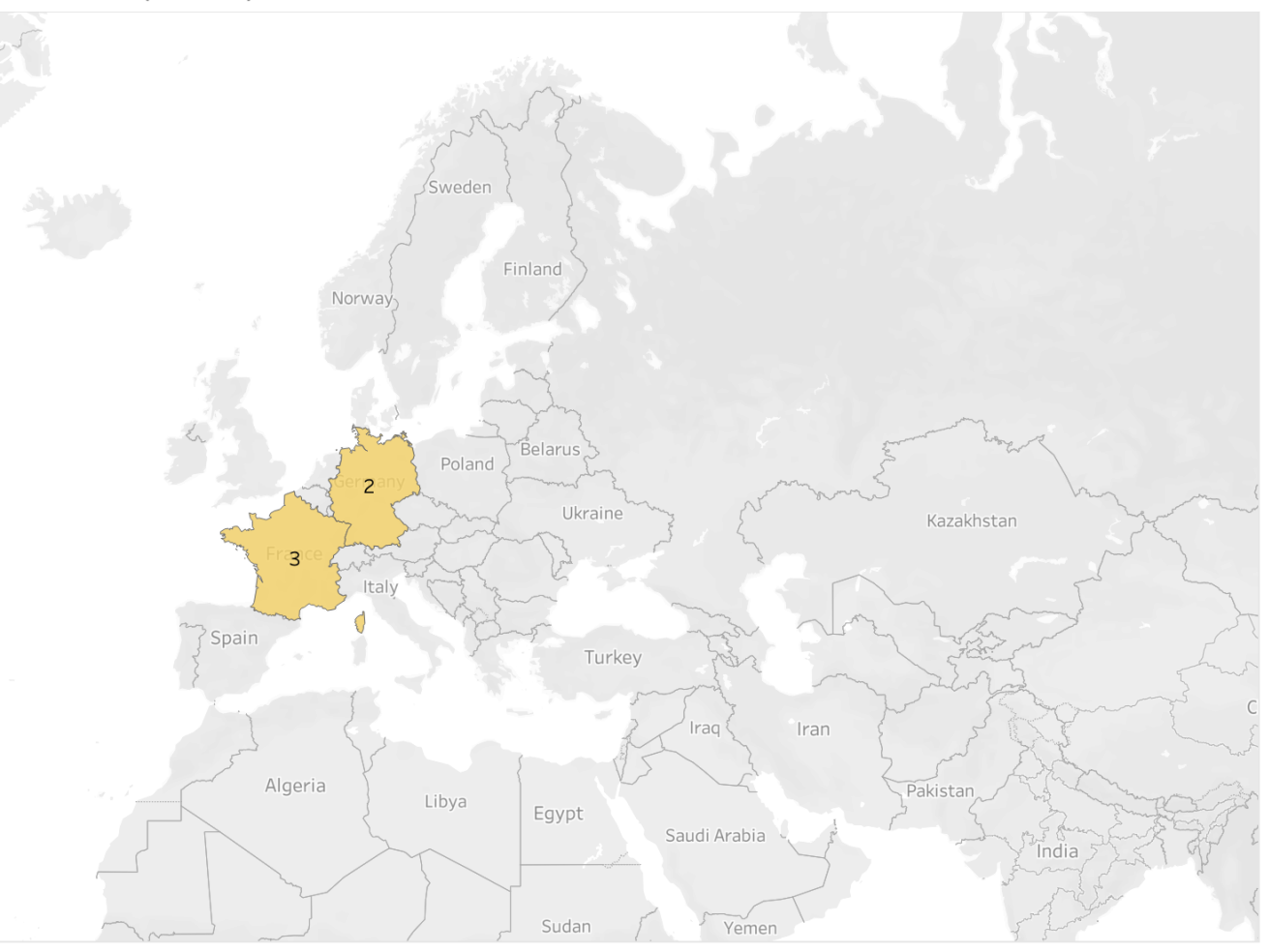

\section{Distribusi Berdasarkan Kota}

Distribusi Kota

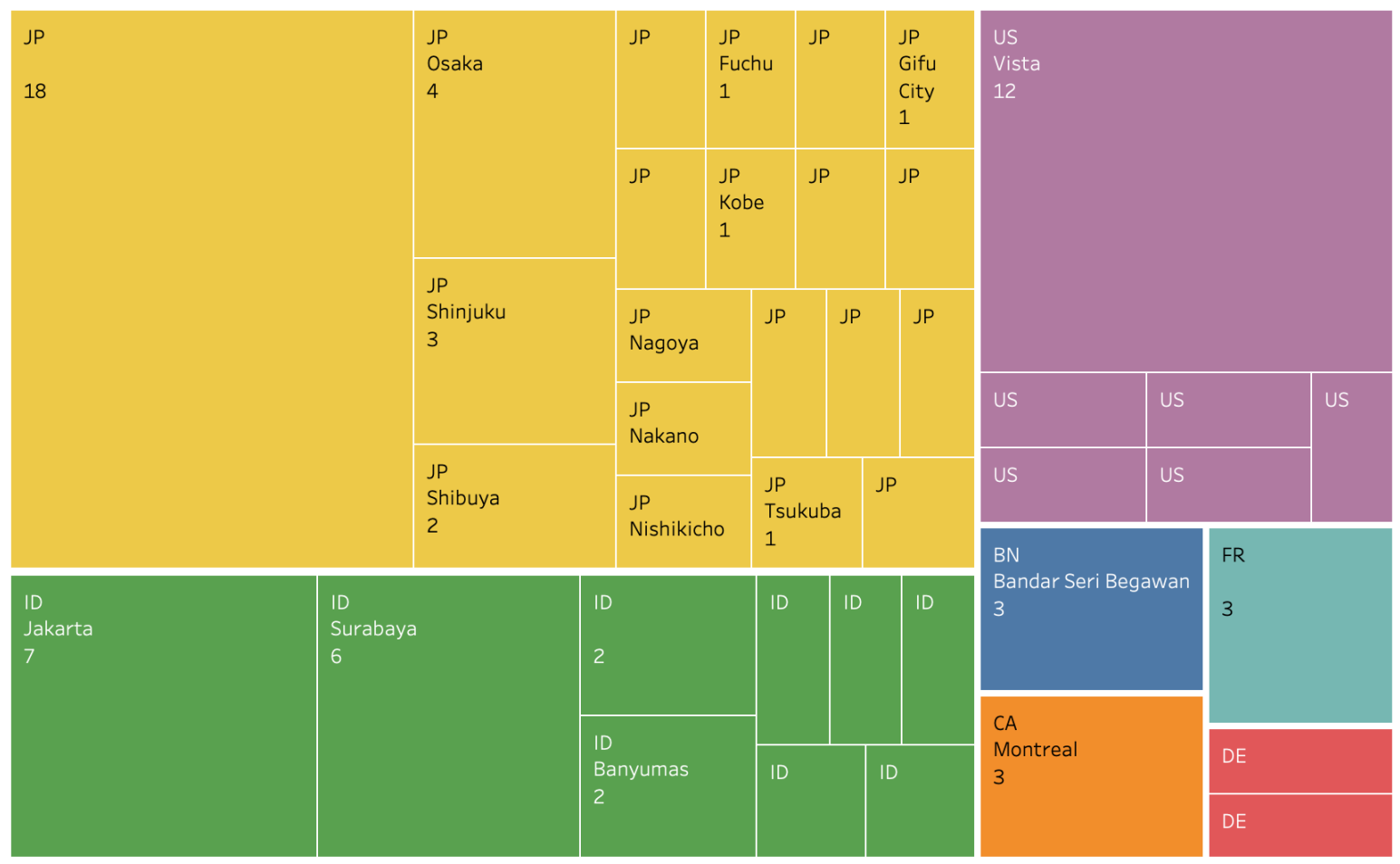




\title{
Analisis Seri \#6
}

\author{
Poster Acara
}

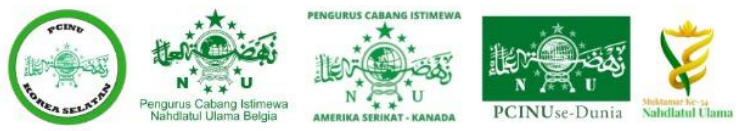

Webinar PCI NU se-Dunia menuju
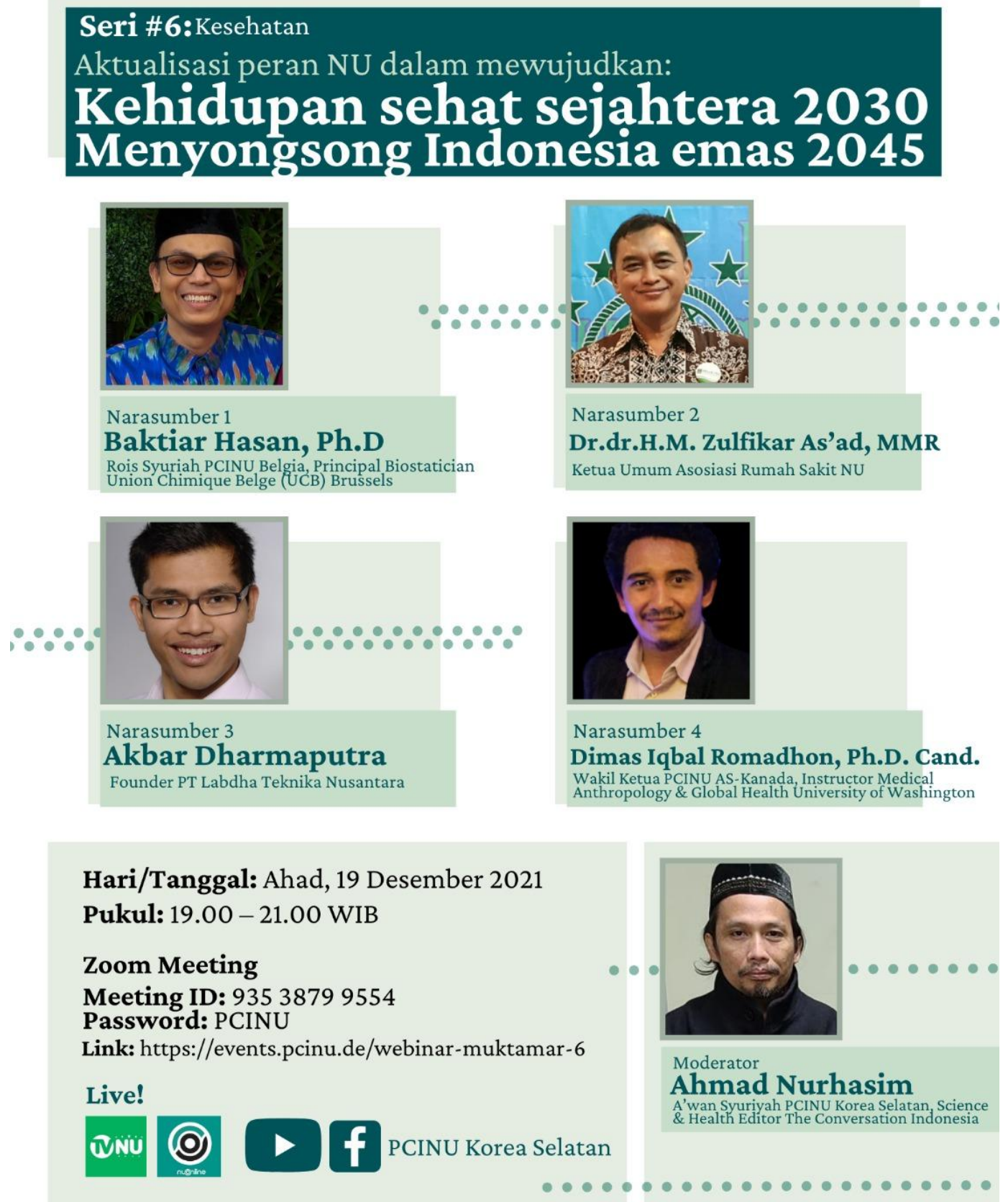
Aktualisasi peran NU dalam mewujudkan Kehidupan Sehat Sejahtera 2030 Menyongsong Indonesia Emas 2045

Ahad, 19 Desember 2021

\section{Total Pengakses}

- Berdasarkan IP address : 114

- Berdasarkan Klik : 129

Distribusi Pengakses Berdasarkan Waktu (CET/Central European Time Zone) Distribusi Waktu

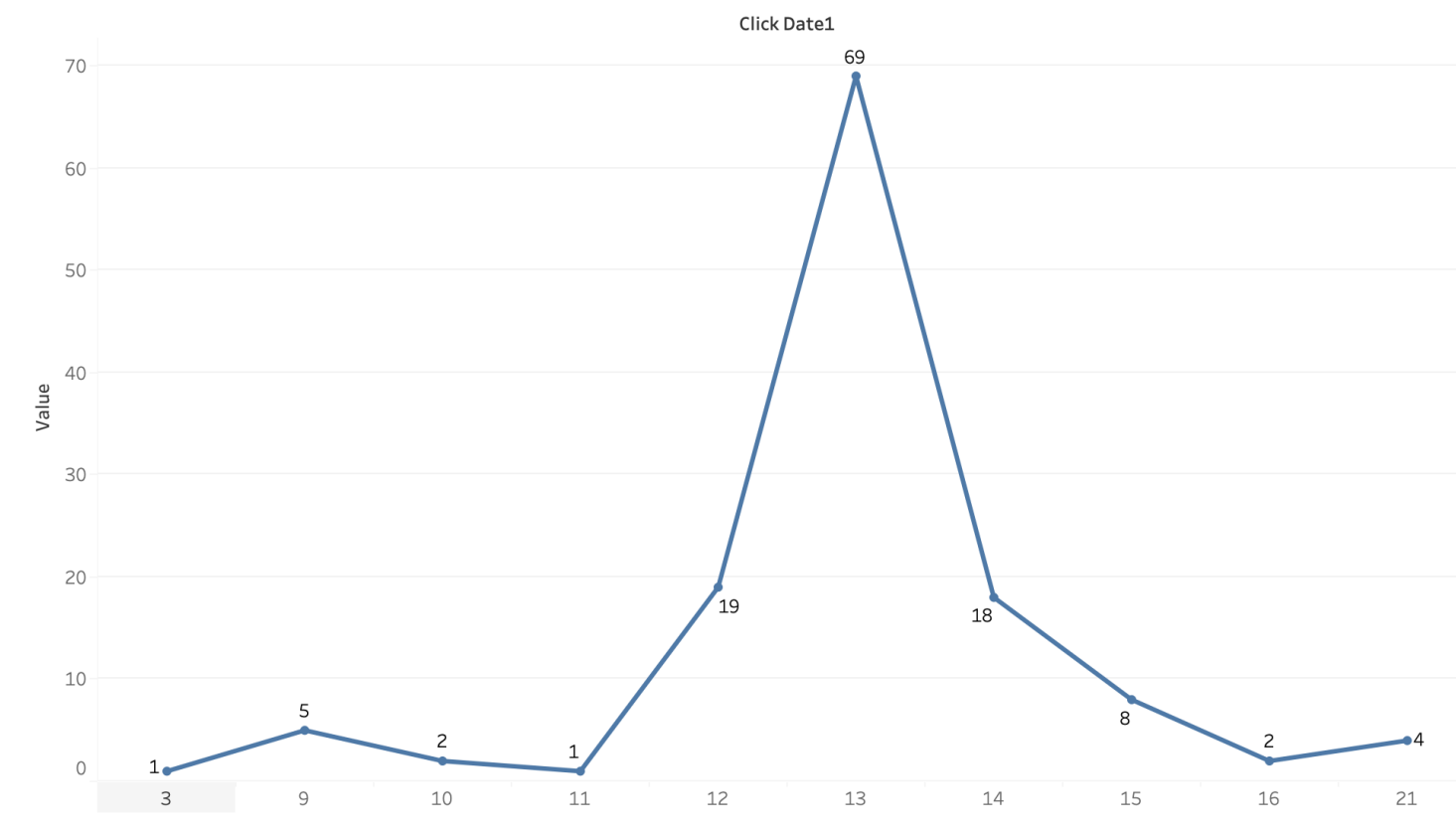

Jenis Perangkat Pengguna

Jenis Perangkat

Mobile Device1

$\mathrm{Nul}$

38

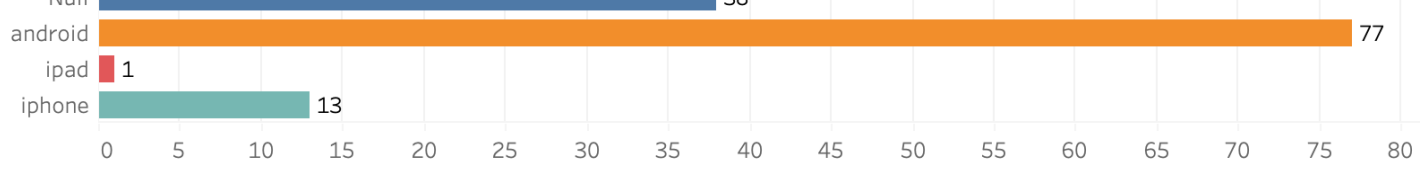

Value 


\section{Distribusi Negara Pengakses}

Distribusi Negara

\section{Country 1}

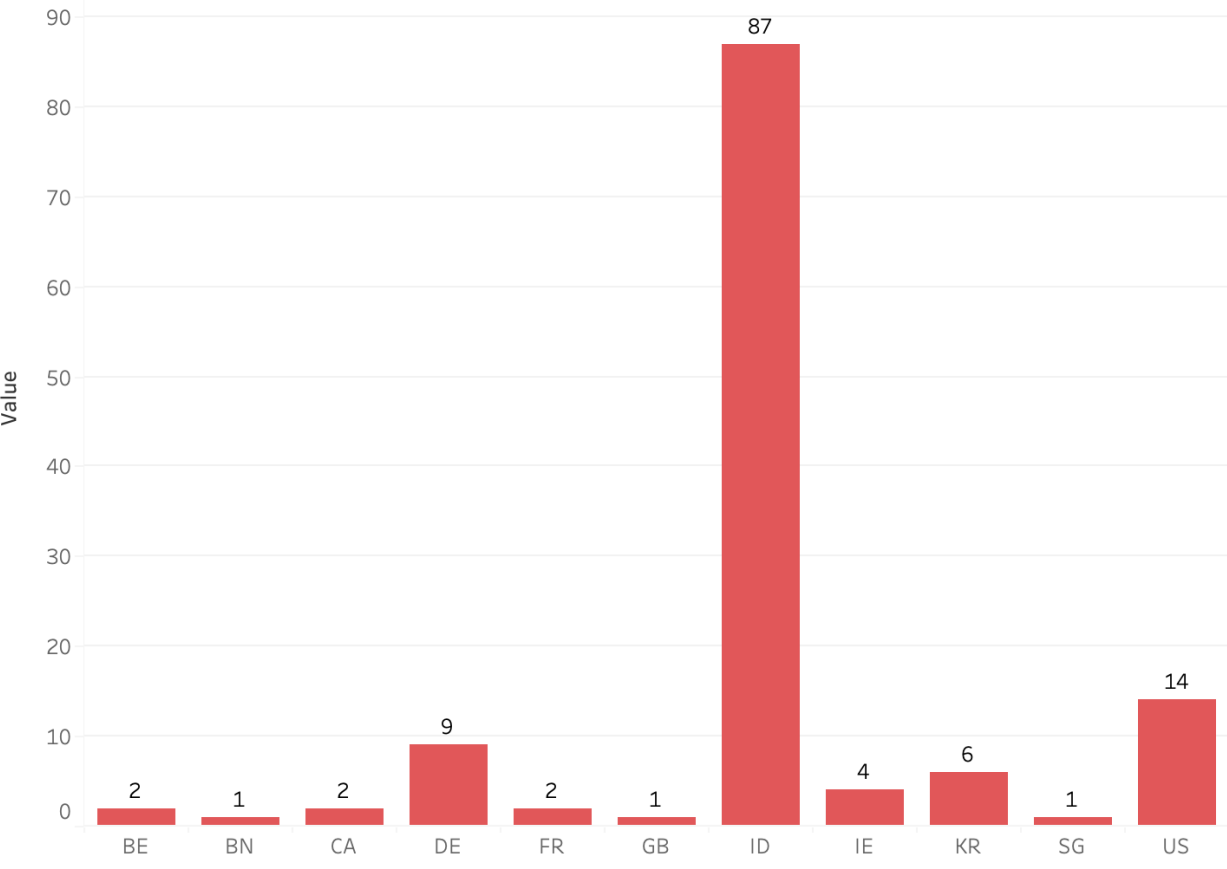

\section{Geografi Negara Pengakses}

Peta Distribusi Negara

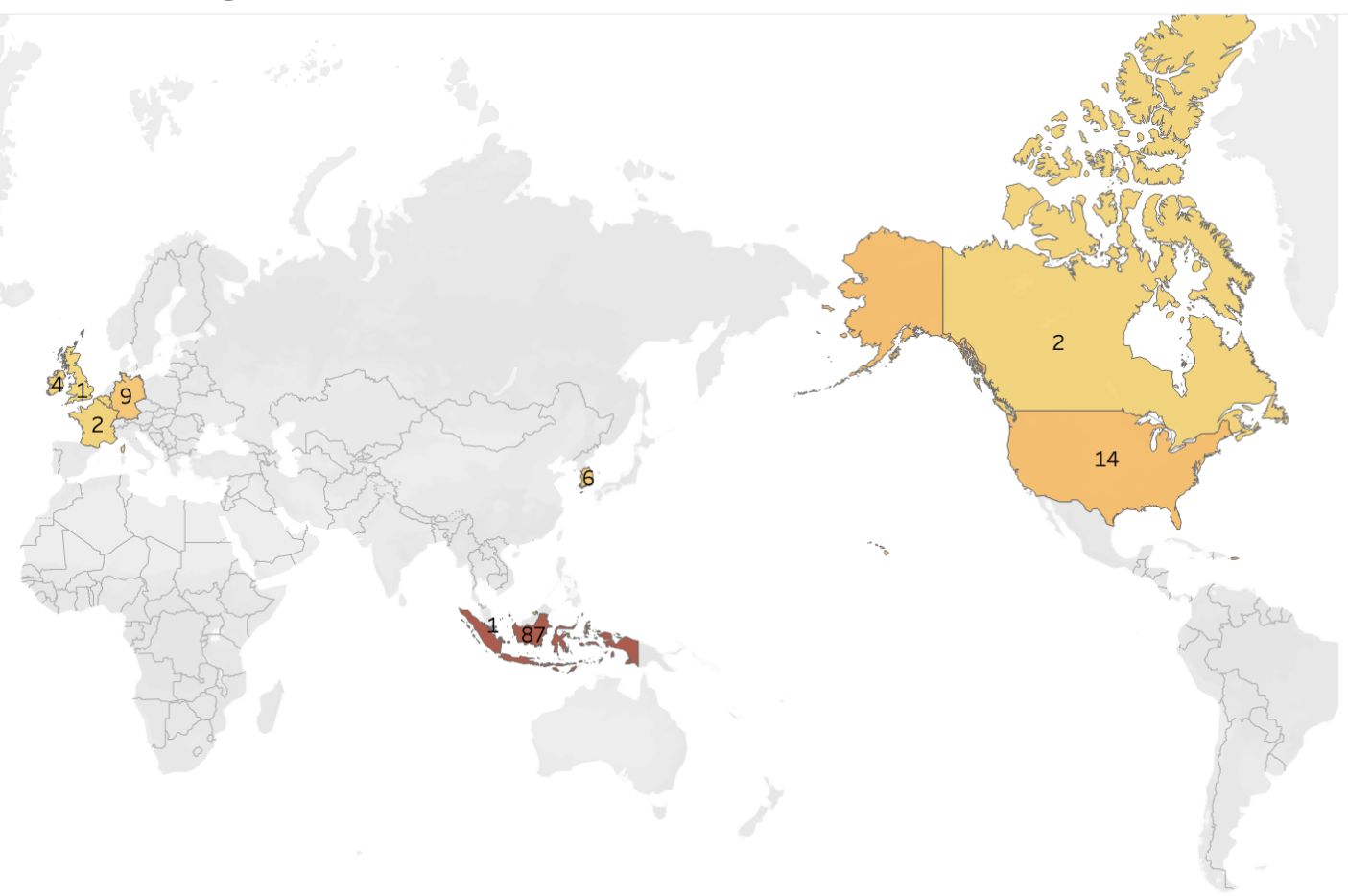


Geografi Negara Pengakses (Eropa)

Peta Distribusi Negara (Eropa)

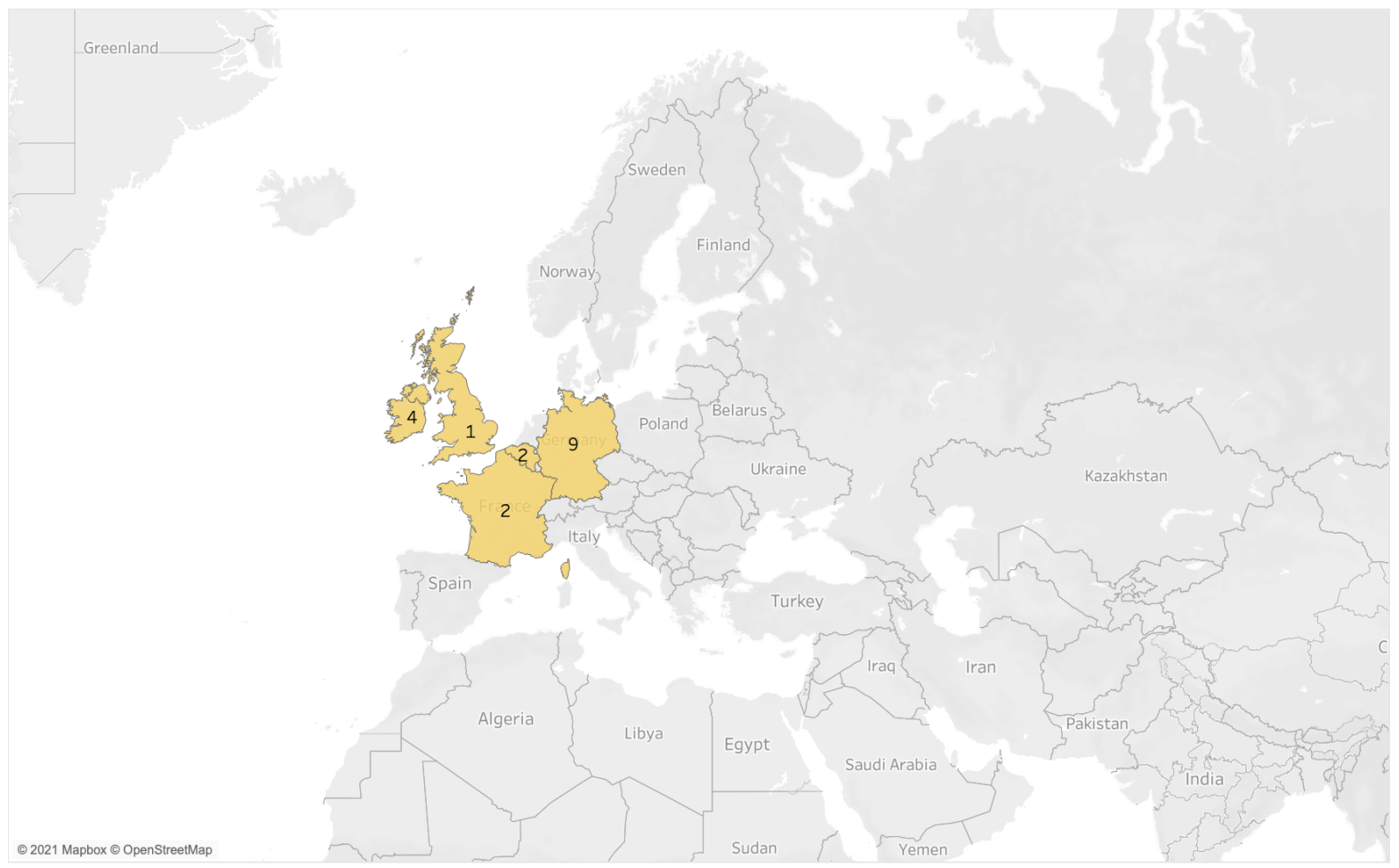

\section{Distribusi Berdasarkan Kota}

Distribusi Kota

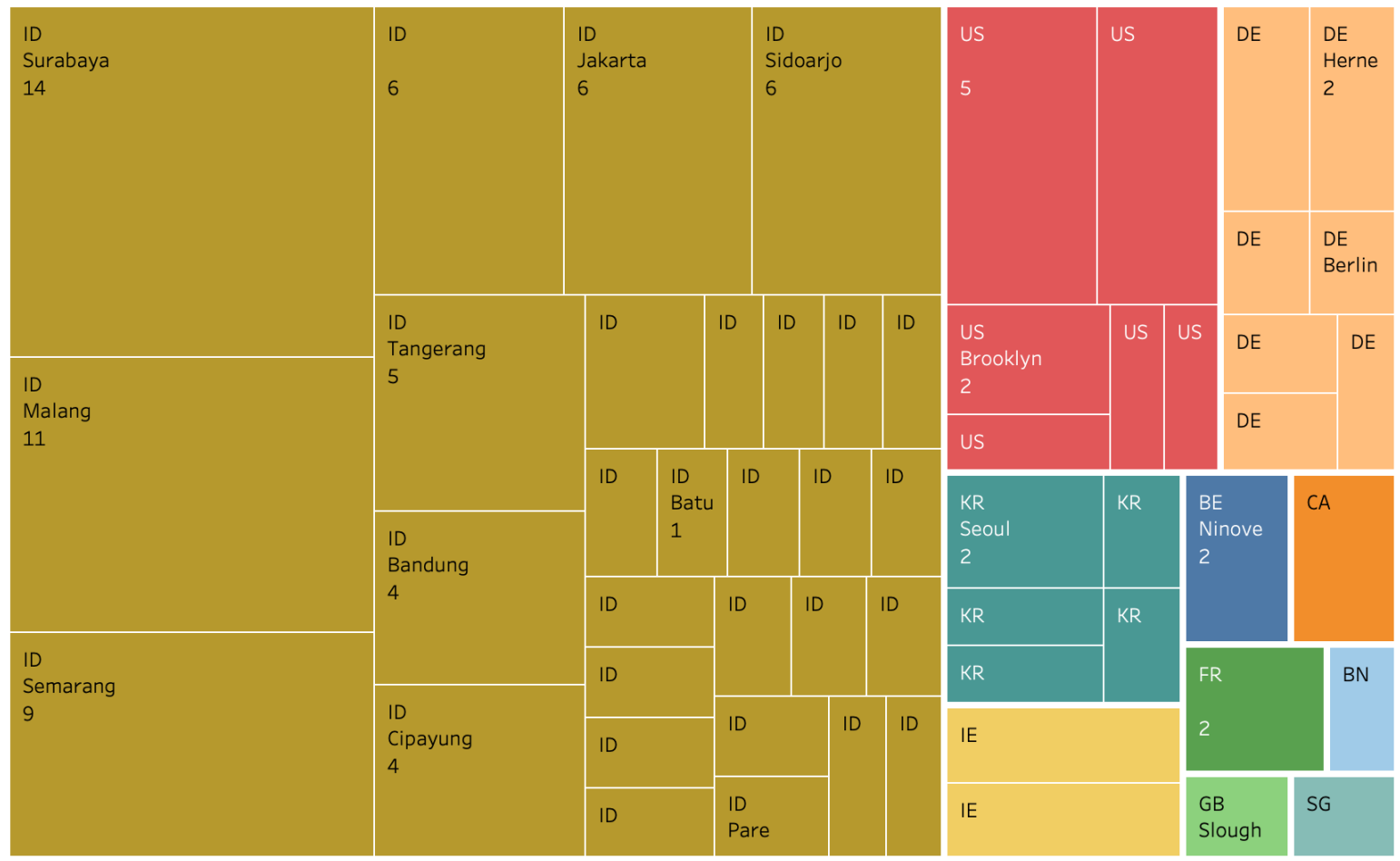




\section{Analisis Seri \#7}

\section{Poster Acara}

WEBINAR

$P R A-N G K A$ P

\section{PCINU} SEDUNIA

Asa Dekolonialisasi dan Repatriasi Pusaka dan Manuskrip Nusantara yang Berada di Europa

0-0-0 Senin / 20 Desember 2021

蹦( Pukul : 19.00-20.00 WIB

\section{Narasumber}

Dr. ZAKI KHAIRUL UMAM

Abdurrahman Wahid Center

Freie Universitaet Berlin

$\sqrt{1}$

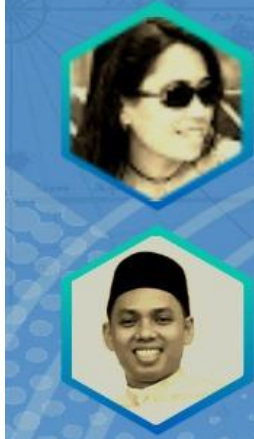

YUS SA'DIYAH-BROERSMA

PCINU Belanda

Bronbeek Museum, Arnhem

\section{NUR ACHMAD}

Dosen UIN Walisongo

Semarang

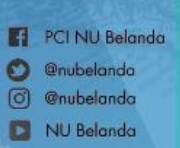

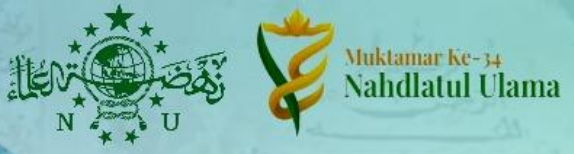

$\mathrm{N} * * * \mathrm{U}$

Di belahan Eropa gembar-gembor dekolonialisasi merebak ke berbagai instansi dan masyakarat, lebih-lebih setelah protes Black Lives matter. Apakah arti dekolonialisasi tersebut? dan apakah relevansinya untuk masyakat Indonesia bekas jajahan bangsa Europa? Apakah impact gerakan dekolonialisasi ini bisa mempengaruhi pemulangan pusaka dan manuskrip Nusantara?

Mari kita bahas... Moderator \& Host

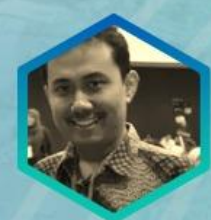

WAHYU WIDODO

PCINU Belanda

Universiteit Leiden

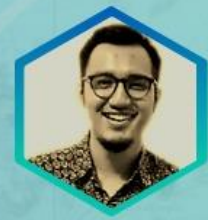

ADRIAN PERKASA

PCINU Belanda

Universiteit Leiden

VIDEO CONFERENCING :

https://events.pcinu.de/webinar-muktamar-7

Organizer :

PCI NU

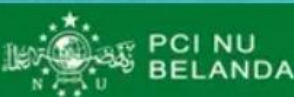

Media Partner :

Wvit nuonline 
Asa dekolonialisasi dan repatriasi pusaka dan manuskrip Nusantara yang berada di Europa

Senin, 20 Desember 2021

\section{Total Pengakses}

- Berdasarkan IP address : 101

- Berdasarkan Klik : 107

Distribusi Pengakses Berdasarkan Waktu (CET/Central European Time Zone) Distribusi Waktu

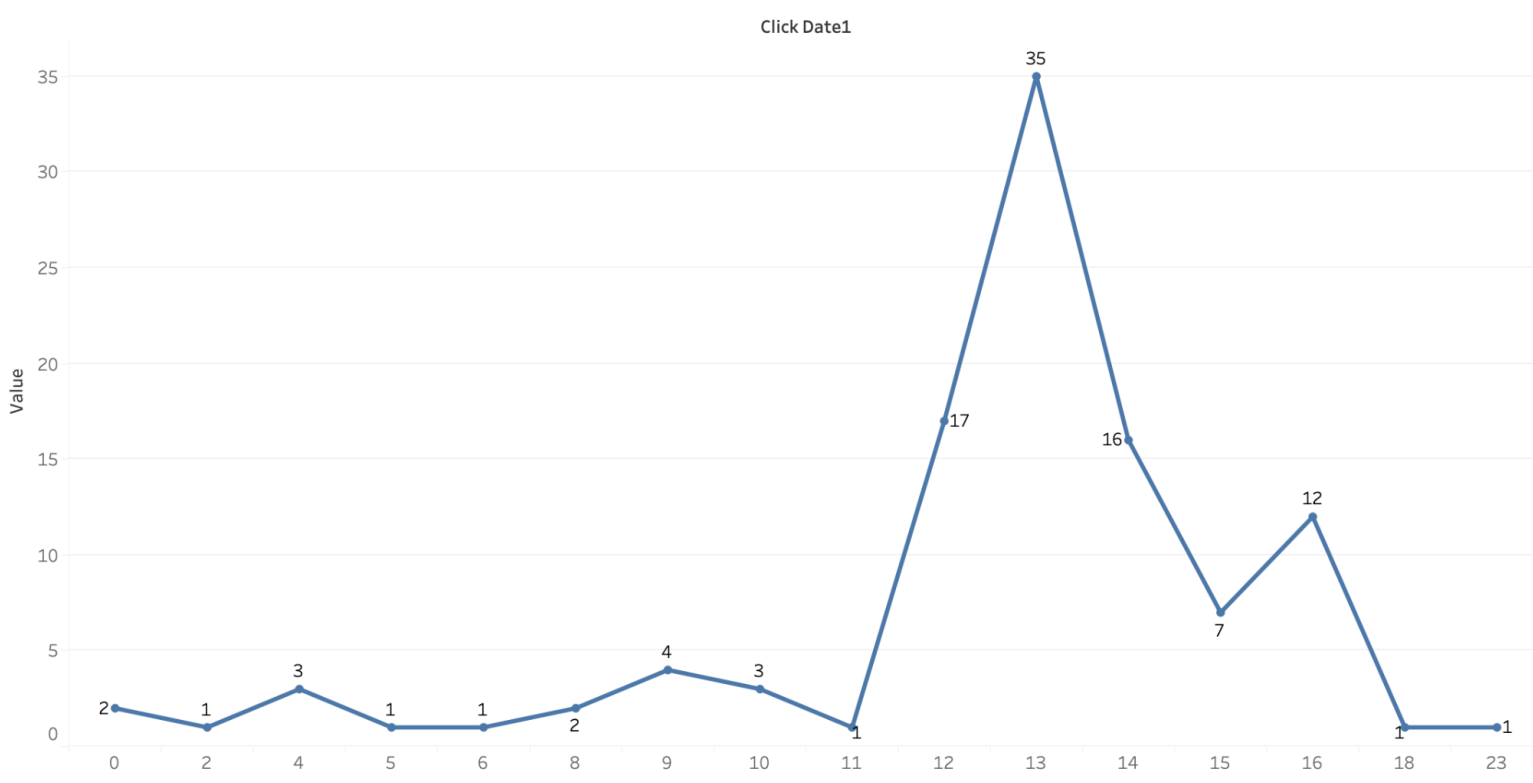

Jenis Perangkat Pengguna

Jenis Perangkat

Mobile Device1
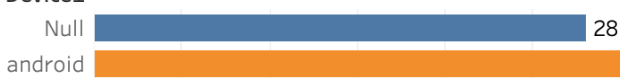

28

iphone

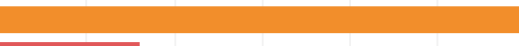

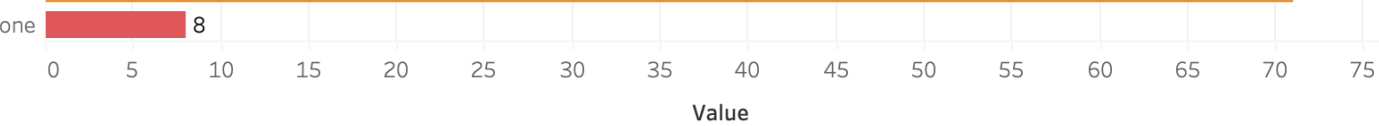




\section{Distribusi Negara Pengakses}

Distribusi Negara

Country1

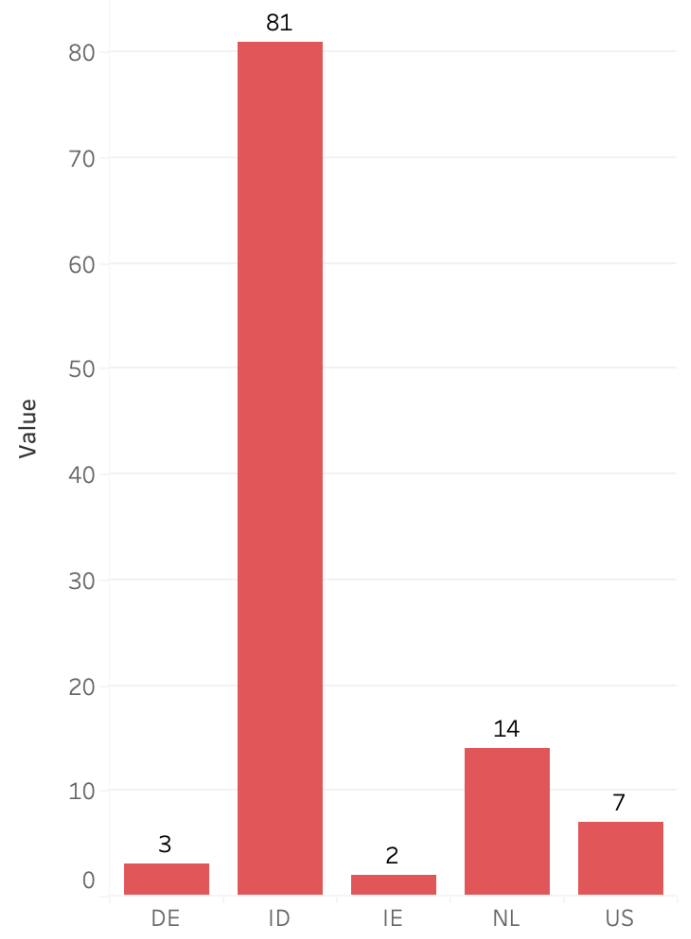

Geografi Negara Pengakses

Peta Distribusi Negara

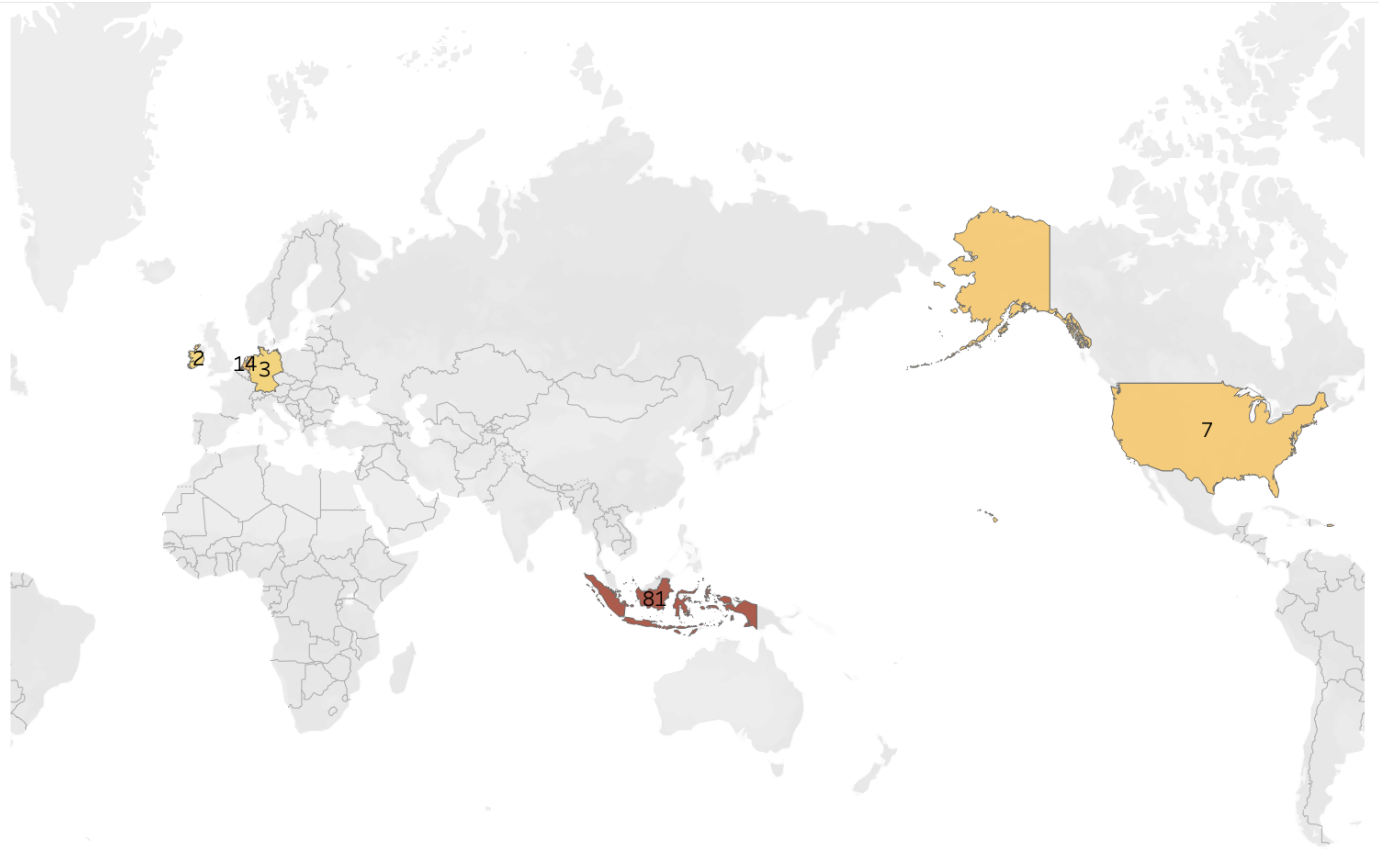


Geografi Negara Pengakses (Eropa)

Peta Distribusi Negara (Eropa)

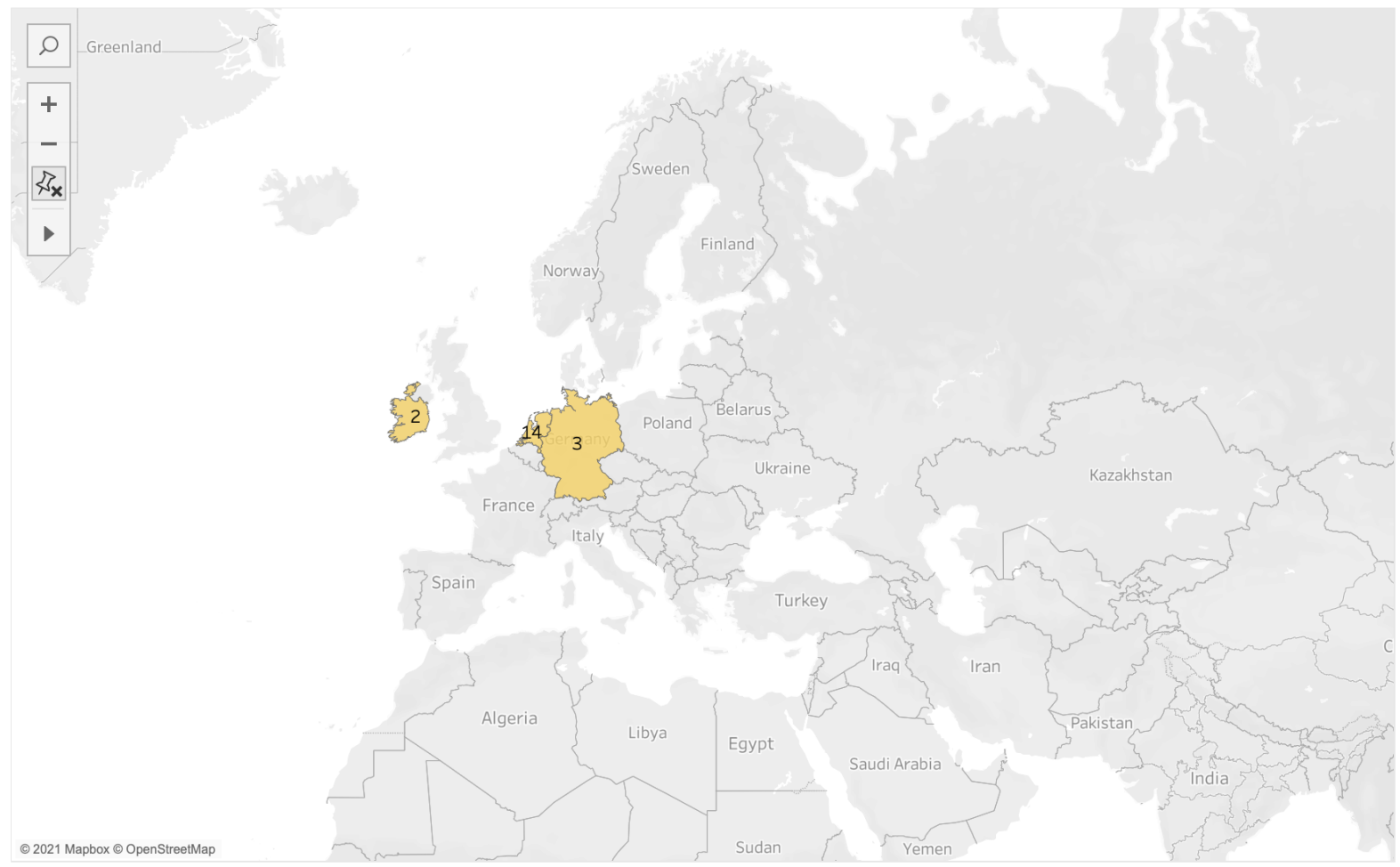

\section{Distribusi Berdasarkan Kota}

Distribusi Kota

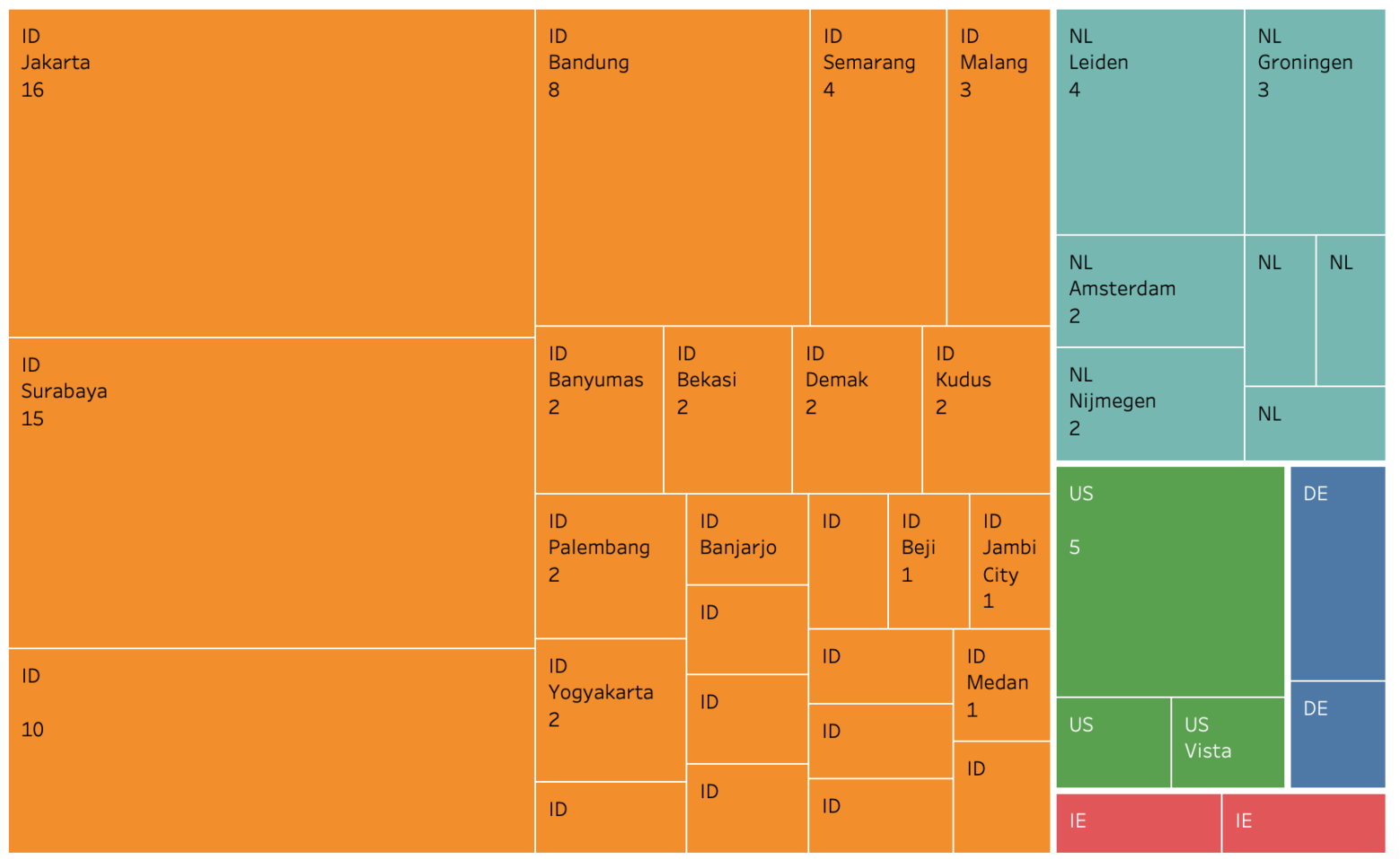




\section{Analisis Seri \#8}

Poster Acara

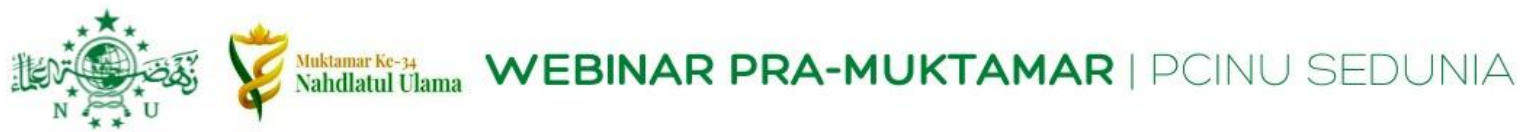

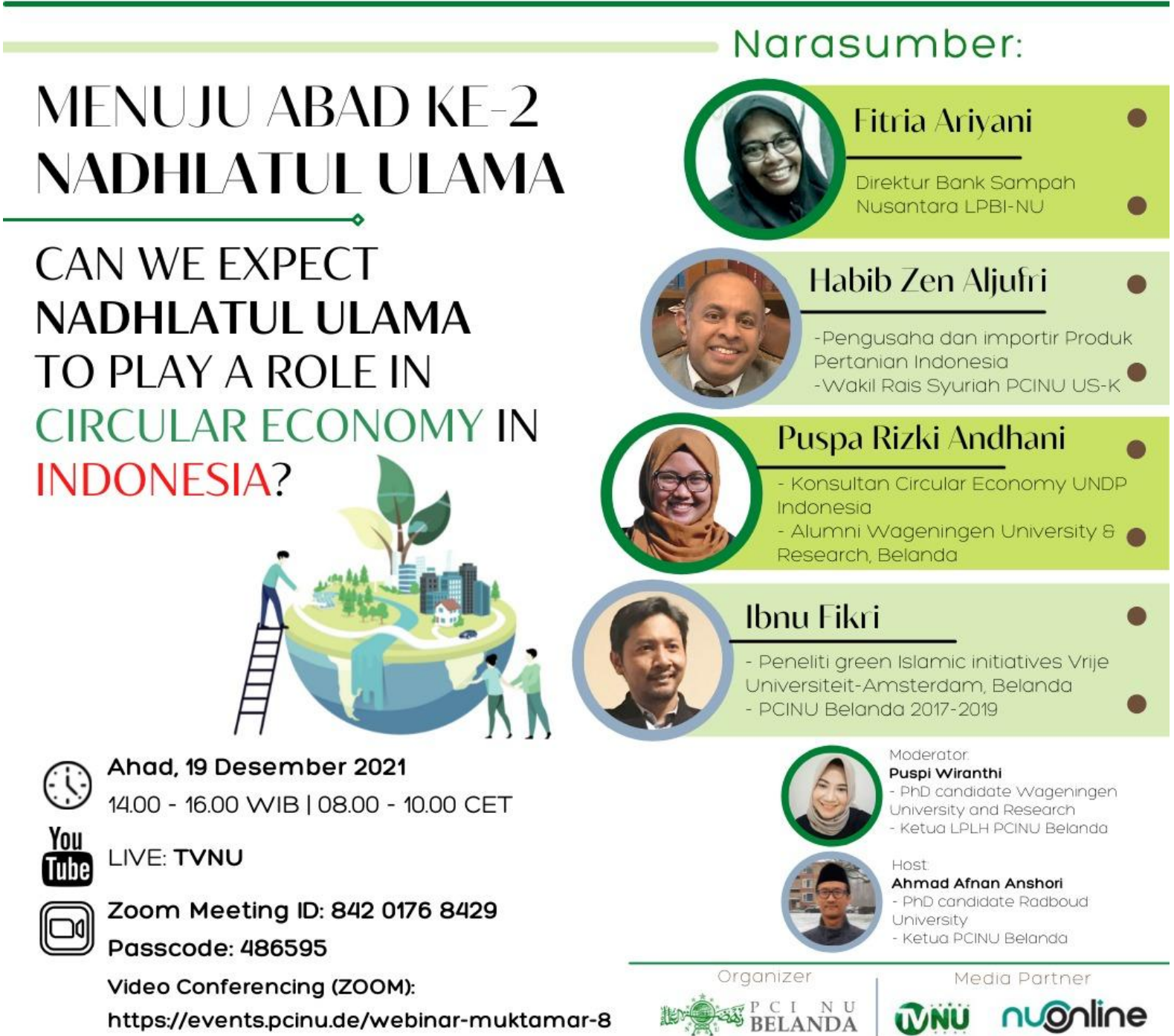


Can We Expect Nahdlatul Ulama to Play A Role in Circular Economy in Indonesia

Ahad, 19 Desember 2021

\section{Total Pengakses}

- Berdasarkan IP address : 67

- Berdasarkan Klik : 75

Distribusi Pengakses Berdasarkan Waktu (CET/Central European Time Zone) Distribusi Waktu

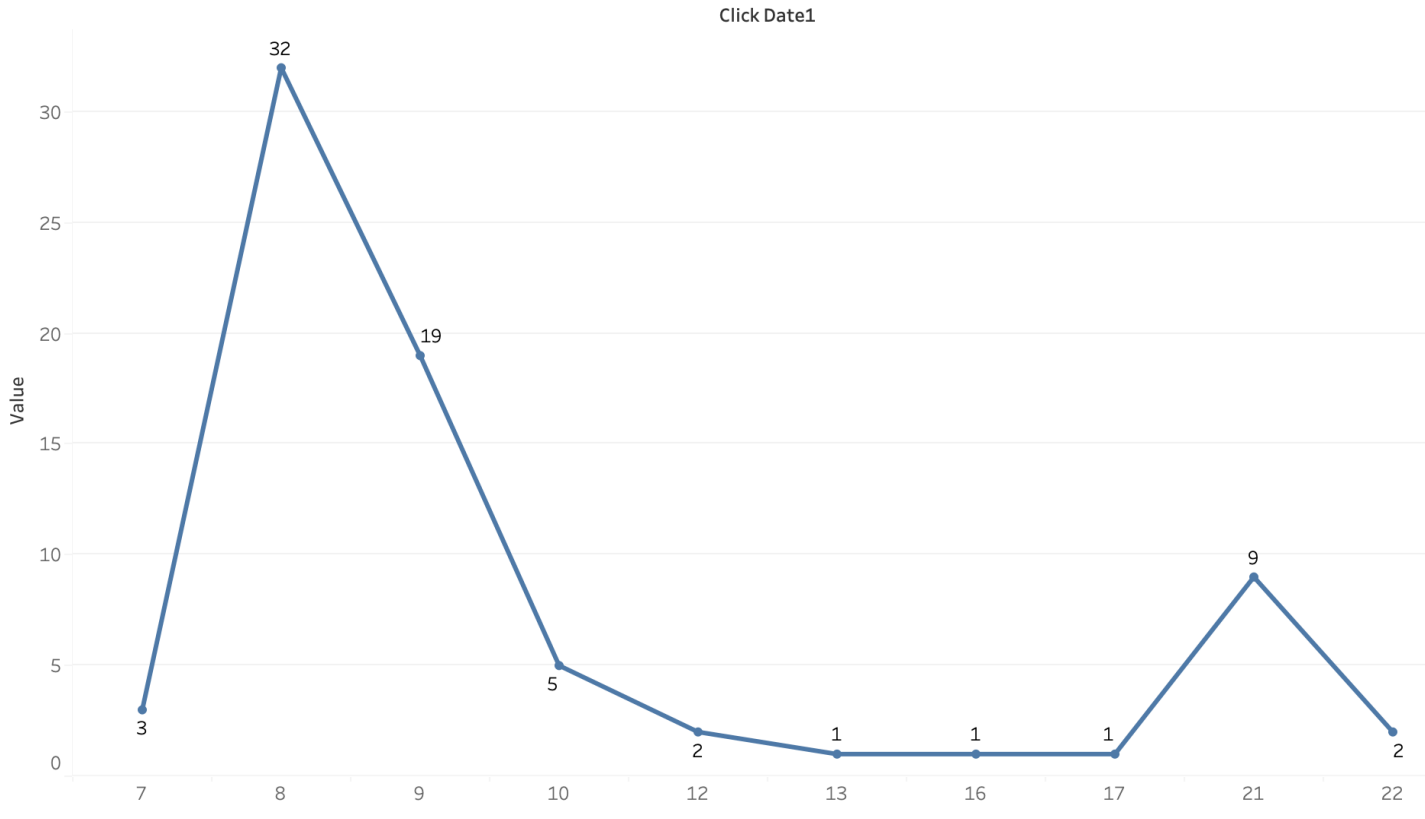

Jenis Perangkat Pengguna

Jenis Perangkat

Mobile Device1

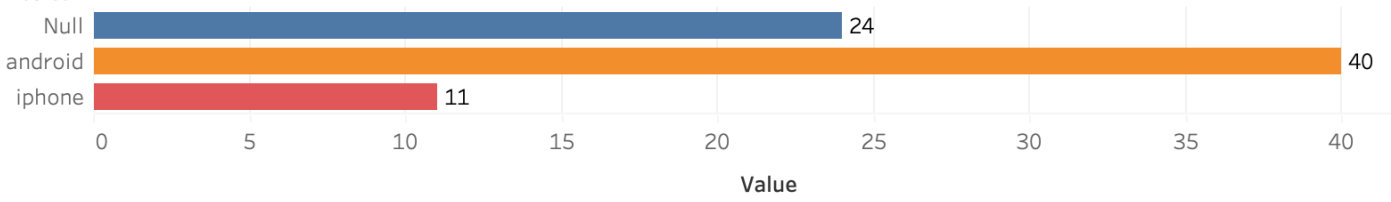




\section{Distribusi Negara Pengakses}

Distribusi Negara

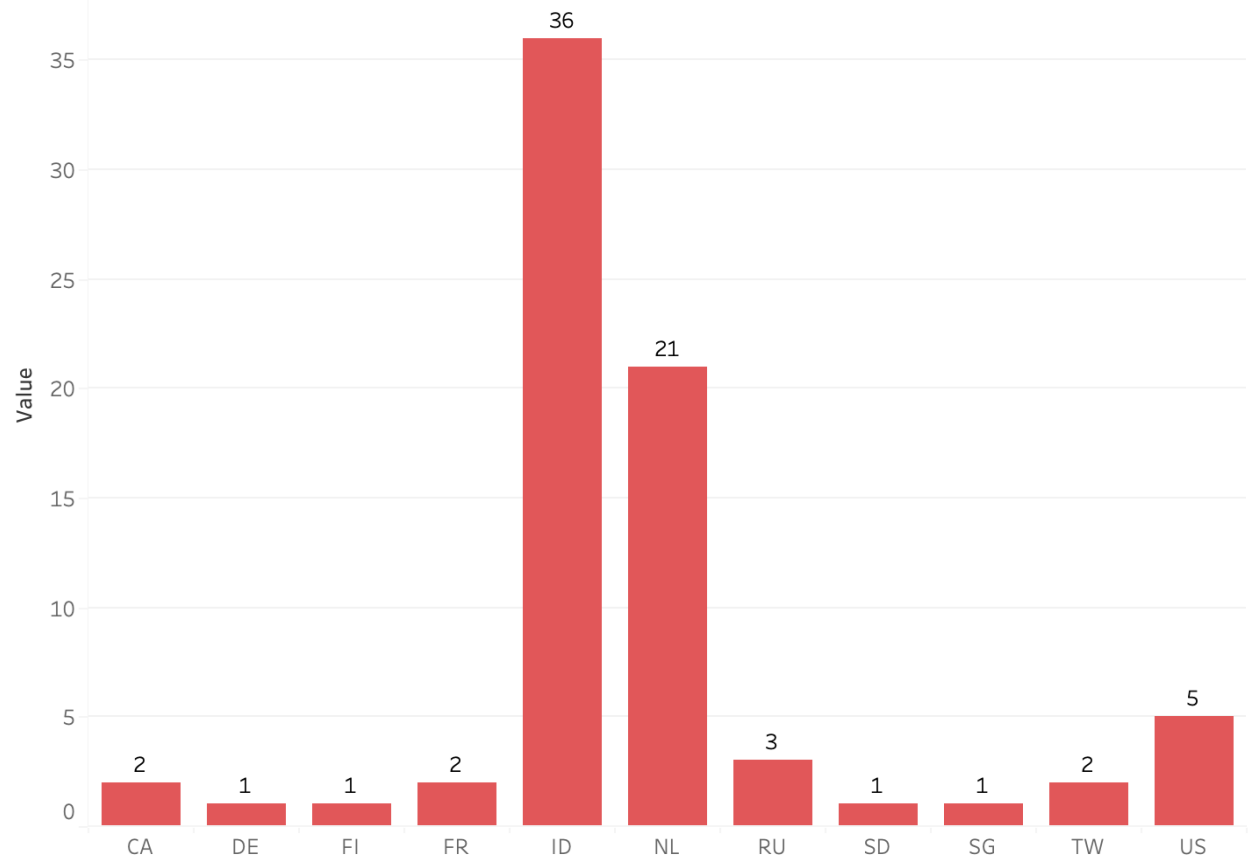

\section{Geografi Negara Pengakses}

Peta Distribusi Negara

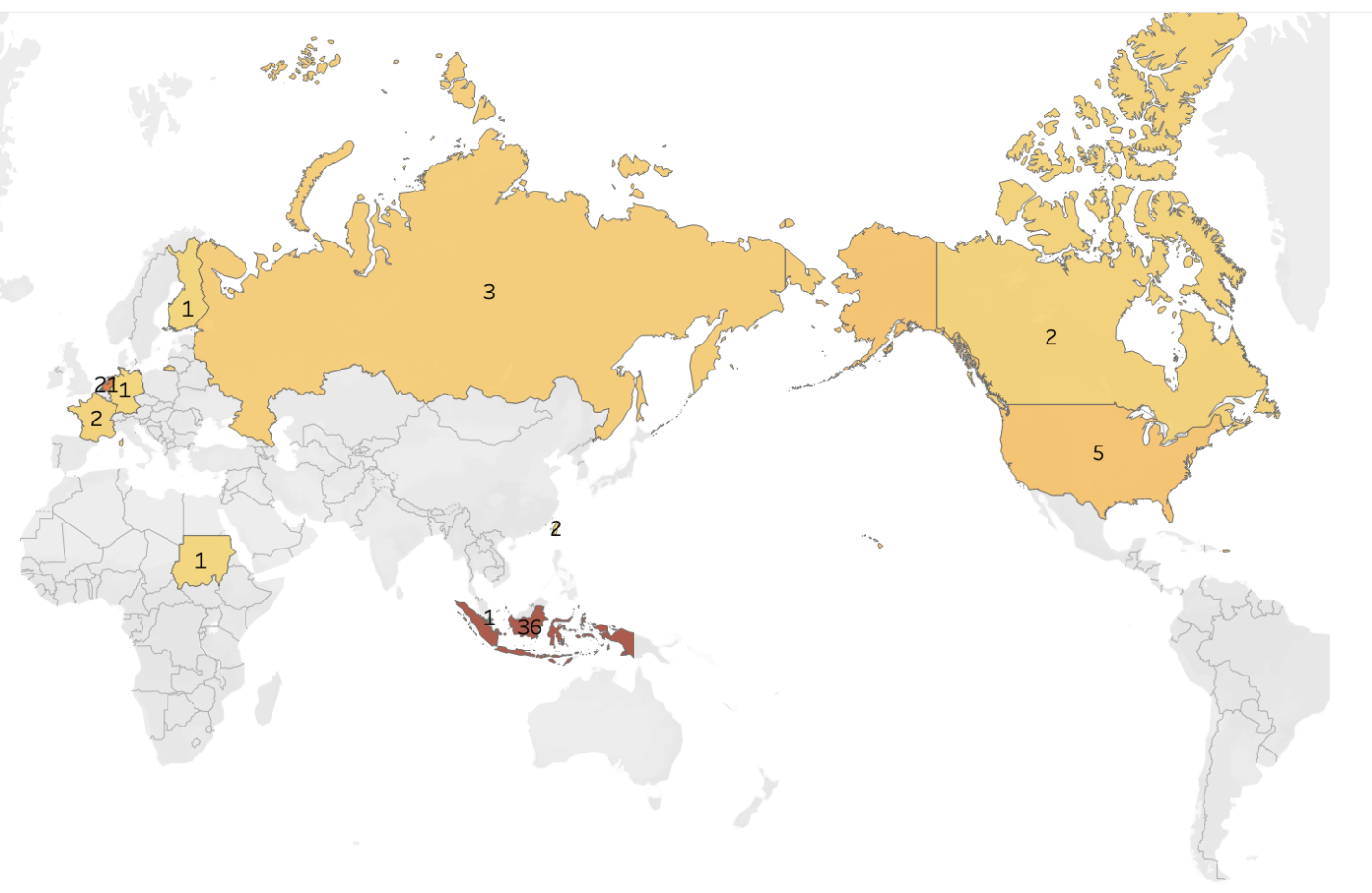


Geografi Negara Pengakses (Eropa)

Peta Distribusi Negara (Eropa)

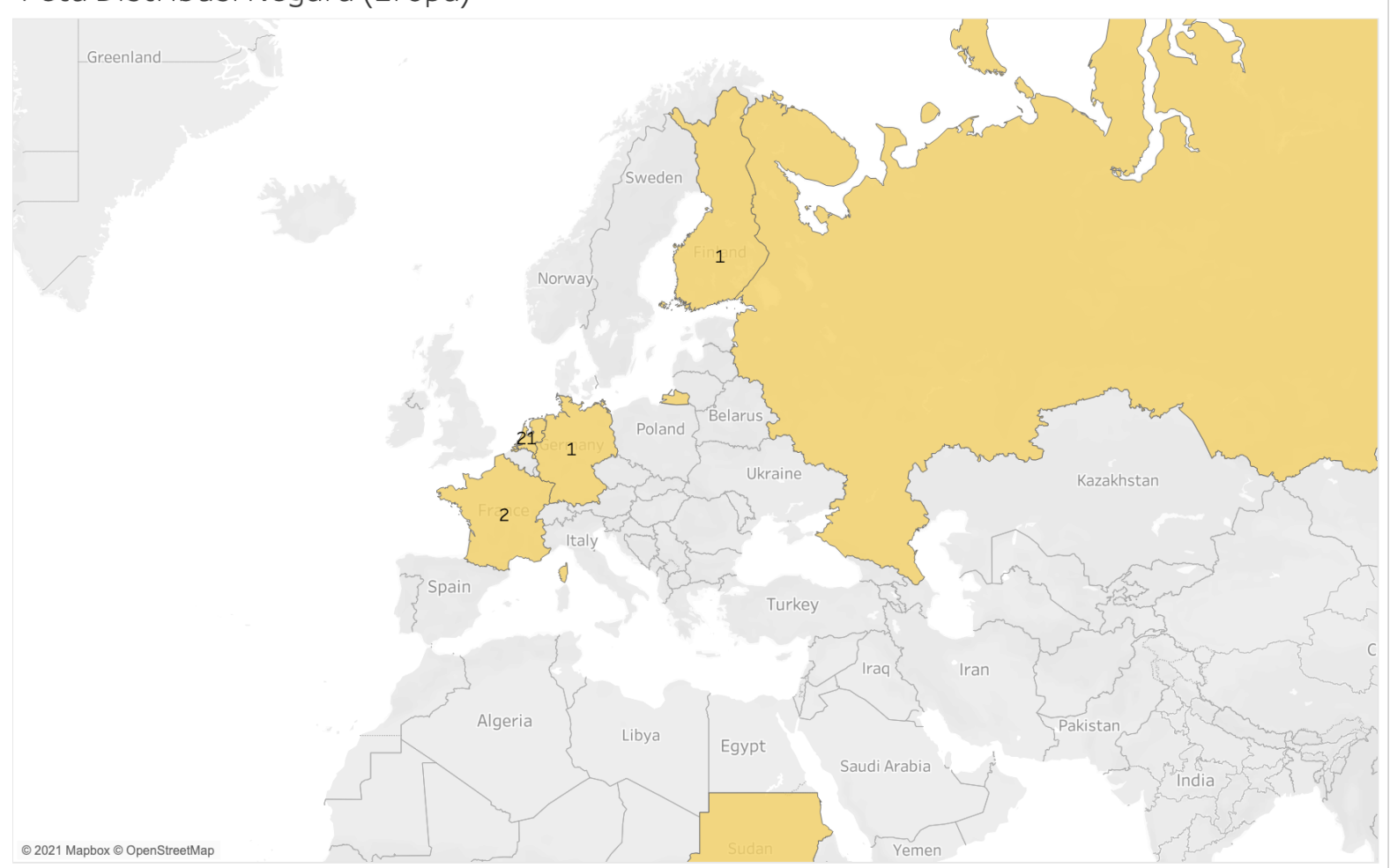

\section{Distribusi Berdasarkan Kota}

Distribusi Kota

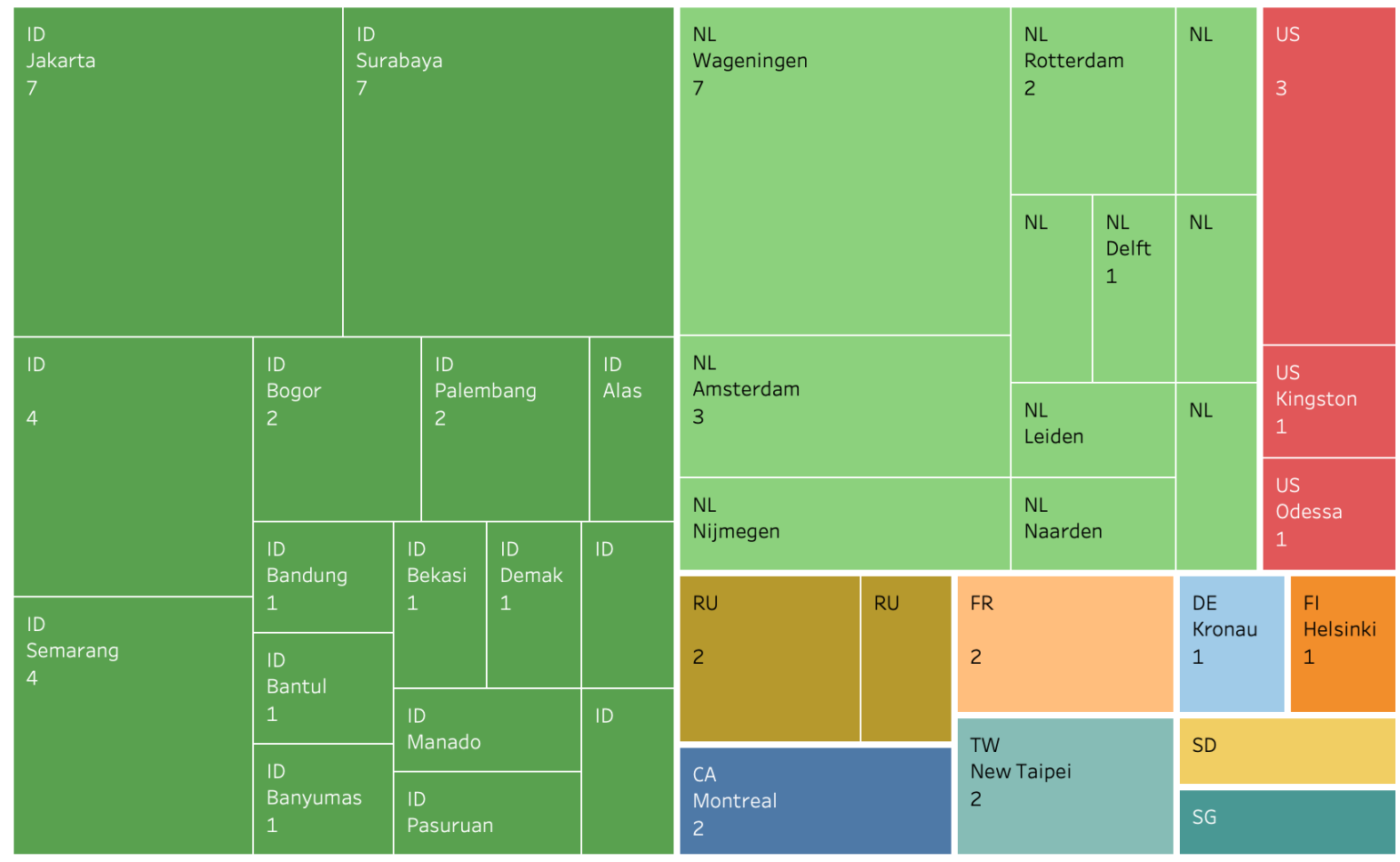




\section{Glosarium}

\section{Kode Negara}

$\begin{array}{ll}\mathrm{AU} & =\text { Australia } \\ \mathrm{BN} & =\text { Brunei Darussalam } \\ \mathrm{BE} & =\text { Belgium } \\ \mathrm{CA} & =\text { Canada } \\ \mathrm{DE} & =\text { Germany } \\ \mathrm{EG} & =\text { Egypt } \\ \mathrm{FI} & =\text { Finland } \\ \mathrm{FR} & =\text { France } \\ \mathrm{GB} & =\text { United Kingdom } \\ \mathrm{HK} & =\text { Hong Kong } \\ \mathrm{ID} & =\text { Indonesia } \\ \mathrm{IE} & =\text { Ireland } \\ \mathrm{IN} & =\text { India } \\ \mathrm{IR} & =\text { Iran } \\ \mathrm{JP} & =\text { Japan } \\ \mathrm{KR} & =\text { Republic of Korea } \\ \mathrm{MA} & =\text { Morocco } \\ \mathrm{MN} & =\text { Mongolia } \\ \mathrm{NL} & =\text { Netherlands } \\ \mathrm{NU} & =\text { Niue } \\ \mathrm{RO} & =\text { Romania } \\ \mathrm{RU} & =\text { Russian Federation } \\ \mathrm{SA} & =\text { Saudi Arabia } \\ \mathrm{SD} & =\text { Sudan } \\ \mathrm{SG} & =\text { Singapore } \\ \mathrm{TN} & =\text { Tunisia } \\ \mathrm{TW} & =\text { Taiwan } \\ \mathrm{US} & =\text { United States of America } \\ \mathrm{VN} & =\text { Vietnam } \\ & \end{array}$

